\title{
Engineering geological and geotechnical investigations of dam of the Bunakha Hydroelectric Project (180 MW), Chukha Dzong, Bhutan Himalaya
}

\author{
A. K. Naithani ${ }^{1, *}$, P. C. Nawani ${ }^{2}$, L. G. Singh ${ }^{1}$ and D. S. Rawat ${ }^{1}$ \\ ${ }^{I}$ National Institute of Rock Mechanics, Kolar Gold Fields - 563 117, India \\ ${ }^{2}$ H.No. G-202, JMD Garden, Sector 33, Gurgaon, 122 001, India \\ *Corresponding author: ajay_naithani@hotmail.com
}

\begin{abstract}
A $197 \mathrm{~m}$ high roller compacted concrete gravity dam is proposed across river Wang Chhu in Chukha Dzong of the Bhutan Himalaya. Bunakha Dam will be the third highest dam constructed by India after the Tehri Dam and Bhakra Dam. The Bunakha Dam site area is located in the Thimpu Formation of the Himalayan crystalline complex. This litho-units at site is characterized by heterogeneous lithology consisting of viz. banded gneisses, foliated gneisses, with large boudins and bands of quartzite and calc-silicate gneisses with large porphyroblasts of garnet measuring up to $4 \mathrm{~mm}$. These litho units form the foundation of proposed dam. In this paper attempt has been made to bring out the rock mass condition of the foundation of dam of the proposed scheme on the basis of detailed engineering geological mapping, geological logging of drill holes, rock mass permeability values, 3D mapping of exploratory drifts, geophysical profiling, in-situ and laboratory test results. Rock mass classification using Rock Mass Rating (RMR) system and Q-system was done. The basic purpose of these investigations was to identify/map different rocks and structures like joints, shear zones, faults, fracture zones etc. and to determine engineering properties of rock and rock mass by lab and in-situ testing and to provide basic data for economic and fail-safe design of the dam. On the basis of these investigations suitable recommendations have been made which will be helpful during the construction of the dam.
\end{abstract}

Key words: Hydroelectric, rock mass classification, roller compacted concrete gravity dam, Thimphu Formation, Bhutan Himalaya

Received: December 25, 2013

Revision accepted: June 15, 2014

\section{INTRODUCTION}

The proposed Bunakha Hydroelectric Project (BHEP) for generation of $180 \mathrm{MW}(3 \mathrm{X} 60 \mathrm{MW}$ ) hydropower is located near village Bunakha, in Chukha Dzong (District) in the Western Bhutan. BHEP is the upper most major project in the development of the power potential of the Wang Chhu River in Bhutan. Wang Chhu is formed by the confluence of two major snow-fed rivers viz. Paro Chhu and Thimphu Chhu, originating from Chomolhari glaciers in the Himalaya at an elevation of the order of 6500 to $7300 \mathrm{~m}$. The catchment area up to proposed Bunakha dam site is 3540 sq.km., out of which $34 \mathrm{sq} \mathrm{km}$ is above $5000 \mathrm{~m}$ elevation, considered as area covered by permanent snow. The Paro Chhu and Thimphu Chhu join at an elevation of $2068 \mathrm{~m}$ at Chhuzom i.e. upstream from the proposed project site (Fig. 1). BHEP is a storage project utilising the head between upstream of the existing Chukha Hydro Electric Project (HEP) and the confluence of Paro Chhu and Thimphu Chhu. Further, the capacity generation of commissioned Chukha HEP (336 MW) and Tala HEP (1020
MW) and planned Wang Chhu HEP (600 MW) will also be increased by the development of BHEP because of regulated flow.

This proposed storage scheme envisages important structures such as concrete dam, spillway, pressure shafts (penstock), dam toe surface power house and tail race channel. Alignment of the dam axis is $\mathrm{N}^{\circ} 0^{\circ} 56^{\prime} \mathrm{E}-\mathrm{S} 70^{\circ} 56^{\prime} \mathrm{W}$ and is located $3.25 \mathrm{~km}$ upstream of existing Chukha dam and is presently approachable by $3 \mathrm{~km}$ long foot path connecting Phuentsholing-Thimphu highway at $102 \mathrm{~km}$ milestone from Phuentsholing. The proposed dam and surface power house facilities at BHEP can utilize a head of $141.62 \mathrm{~m}$. The estimated gross storage of this project is about $329.16 \mathrm{MCM}$. The proposed dam is a roller compacted concrete type, with Orifice type spillway. The maximum height of the dam will be $197 \mathrm{~m}$ above the deepest foundation level i.e. EL 1813.0 $\mathrm{m}$. The top elevation of the dam is at EL $2010.0 \mathrm{~m}$ plus $1 \mathrm{~m}$ wave protection wall and length of dam at top is $429.5 \mathrm{~m}$ and 


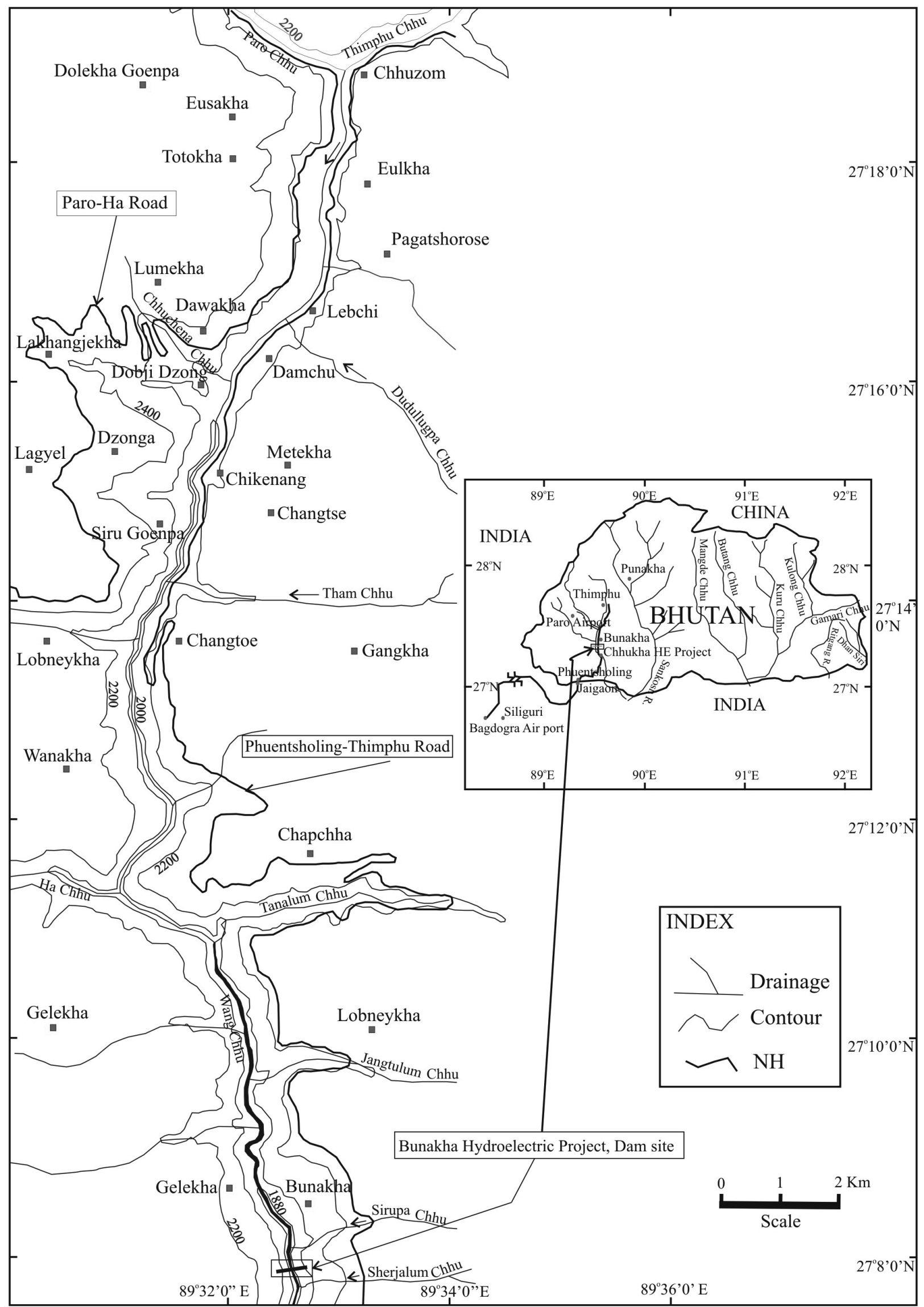

Fig. 1: Location map of the Bunakha Hydroelectric Project and its reservoir area. 
Table 1: Salient features of Bunakha hydroelectric project

\begin{tabular}{|c|c|c|c|c|c|}
\hline S.N. & Description & & S.N. & Description & \\
\hline \multirow[t]{4}{*}{1.} & Location: & & & Crest Level & EL $1915 \mathrm{~m}$ \\
\hline & Country and River & Bhutan and Wangchu & & Energy Dissipation & Flip Bucket \\
\hline & Latitude / Longitude & $\begin{array}{l}27^{\circ} 08^{\prime} 00^{\prime \prime} \mathrm{N} / \\
89^{\circ} 32^{\prime} 33^{\prime \prime} \mathrm{E}\end{array}$ & & Gate Arrangement & $\begin{array}{l}\text { Radial gates of vertical } \\
\text { opening } 9 \mathrm{~m} \text { high by } 6 \mathrm{~m} \text { wide }\end{array}$ \\
\hline & Catchment Area & $3540 \mathrm{~km}^{2}$ & $4 \mathrm{~b}$ & $\begin{array}{l}\text { Gated Auxilary } \\
\text { Spillway: }\end{array}$ & \\
\hline \multirow[t]{8}{*}{2.} & Reservoir: & & & Numbers / Size of Bay & $\begin{array}{l}1 \text { No. / } 4.5 \mathrm{~m} \text { wide by } 4 \mathrm{~m} \\
\text { high in block } 14 \& 15\end{array}$ \\
\hline & $\begin{array}{l}\text { Maximum Water Level } \\
(\mathrm{MWL})\end{array}$ & EL $2008 \mathrm{~m}$ & & Crest Level & EL $2002.0 \mathrm{~m}$ \\
\hline & Full Reservoir Level (FRL) & EL $2006 \mathrm{~m}$ & & Energy Dissipation & Flip Bucket \\
\hline & $\begin{array}{l}\text { Minimum Draw Down } \\
\text { Level (MDDL) }\end{array}$ & EL $1950 \mathrm{~m}$ & 5. & $\begin{array}{l}\text { Intake (inside dam } \\
\text { body): }\end{array}$ & \\
\hline & Gross Storage & 329.16 Mcum & & Invert Level / Numbers & EL $1940.0 \mathrm{~m} / 3$ Nos. \\
\hline & Live Storage & 250.62 Mcum & 6. & Pressure Shaft: & \\
\hline & $\begin{array}{l}\text { Area Under Submergence } \\
\text { at FRL }\end{array}$ & $6.82 \mathrm{~km}^{2}$ & & Number / Length & 3 Nos. / $200 \mathrm{~m}$ \\
\hline & Length of the Reservoir & $\begin{array}{l}17.25 \mathrm{~km} \text { at FRL of EL } \\
2006 \mathrm{~m}\end{array}$ & & Diameter / Shape & $3.5 \mathrm{~m} /$ Circular \\
\hline \multirow[t]{7}{*}{3.} & Dam: & & 7. & Power House: & \\
\hline & Type & $\begin{array}{l}\text { Roller Compacted } \\
\text { Concrete }\end{array}$ & & Type & Surface type at Dam Toe \\
\hline & $\begin{array}{l}\text { Top Width / Bottom Width } \\
\text { at Maximum Section }\end{array}$ & $12 \mathrm{~m} / 196 \mathrm{~m}$ & & Rated Head & $141.62 \mathrm{~m}$ (net) \\
\hline & Top Elevation of Dam & $\begin{array}{l}\text { EL } 2010.0 \mathrm{~m}+1 \mathrm{~m} \\
\text { wave protection wall }\end{array}$ & & $\begin{array}{l}\text { Type of Turbine and No. } \\
\text { of Units }\end{array}$ & $\begin{array}{l}\text { Vertical Francis, } 3 \text { Units of } \\
60 \mathrm{MW} \text { each }\end{array}$ \\
\hline & Deepest Foundation Level & EL $1813.0 \mathrm{~m}$ & & Installed Capacity & $180 \mathrm{MW}$ \\
\hline & Dam Height & $\begin{array}{l}197 \mathrm{~m} \text { (above deepest } \\
\text { foundation level }\end{array}$ & & $\begin{array}{l}\text { Minimum Tail Water } \\
\text { Level }\end{array}$ & EL $1842.1 \mathrm{~m}$ \\
\hline & Length of Dam at the Top & $429.5 \mathrm{~m}$ & & $\begin{array}{l}\text { Maximum TWL (PMF - } \\
\text { 10028) }\end{array}$ & EL $1859.3 \mathrm{~m}$ \\
\hline \multirow[t]{2}{*}{4.} & Spillway: & & 8. & Tailrace: & \\
\hline & Type / Routed PMF & $\begin{array}{l}\text { Orifice / } 8756.61 \\
\text { Cumecs }\end{array}$ & & Number / Type & $\begin{array}{l}3 \text { Nos. / Open trough from } \\
\text { draft tube to river }\end{array}$ \\
\hline \multirow[t]{2}{*}{ 4a. } & Low Level Spillway: & & 9. & Power Benefits: & \\
\hline & Numbers / Size of Bays & $\begin{array}{l}6 \text { Nos. / } 6 \mathrm{~m} \text { wide by } 9 \\
\mathrm{~m} \text { high }\end{array}$ & & $\begin{array}{l}\text { Annual Energy Benefits } \\
\text { at Bunakha }\end{array}$ & $753.95 \mathrm{GWh}$ \\
\hline
\end{tabular}

top width is $12 \mathrm{~m}$. Bottom width at maximum section is $196 \mathrm{~m}$. The salient features of the project are given in Table 1.

A concrete gravity structure for Bunakha Dam is preferred because of topography i.e. narrow gorge of Wang Chhu and no suitable site for Chute Spillway and non-availability of suitable quality and volume of impervious soil for core material. The quantity of clayey soil is reported about $13,000 \mathrm{~m}^{3}$ only to be available in clay borrow area within $2 \mathrm{~km}$ from dam axis. Preference has been given to Roller Compacted Concrete (RCC) technology over conventional vibratory technique of compacting concrete because of its shorter construction period and reduced cost. Bunakha will be the third tallest dam constructed by India after constructed Tehri (earthen embankment $261 \mathrm{~m}$ high) and Bhakra dams (concrete gravity $226 \mathrm{~m}$ high). Under RCC category it will the fourth tallest dam in the world after constructed Longtan dam (216.5 m high) in China on River Hongshui and under construction DiamerBhasha dam (272 m high) in Pakistan on River Indus and Gilgel Gibe III dam (240 m high) in Ethiopia on River Omo. The Ghatghar in Maharashtra is the highest dam ( $86 \mathrm{~m}$ high) constructed by India using RCC technology. By understanding RCC technology of bigger dams to be constructed quickly and the technique has been implemented to generate power as fast as possible way.

Geological and geotechnical investigations are essential for hydropower project to assess the suitability of the site, to 
enable an adequate and economic design, to plan the most suitable method of construction, to foresee and provide against difficulties and delays that may arise during construction due to subsurface conditions including groundwater. In this paper, an attempt has been made to perform the rock mass condition of the foundation of dam of the proposed scheme on the basis of detailed engineering geological mapping, geological logging of drill holes, rock mass permeability values, 3D logging of exploratory drifts, geophysical profiling, in-situ and laboratory test result. The basic purpose of these investigations was to identify/map different rocks and structures like joints, shear zones, faults, fracture zones etc. and to determine engineering properties of rock and rock mass by lab and in-situ testing. Rock mass classification using Rock Mass Rating (RMR) system (Bieniawski 1989) and Q-system (Barton et al. 1974) was attempted.

\section{Finalisation of dam axis}

Earlier, feasibility stage geological investigations were carried out by Chowdhury $(1993,1995)$ and Mishra and Sanwal (1994) and the focus was for the dam axis II-A i.e. about $3.20 \mathrm{~km}$ upstream of the existing Chukha dam. The site was geologically more suitable, most of available head will be utilized and reservoir capacity will be increased by about $30 \%$. However, after detailed design, where different components were laid out on the ground, it was observed that the stilling basin gets positioned in front of a left bank nala (Sherjalum $\mathrm{Chhu}$ ) joining Wangchu River about $300 \mathrm{~m}$ downstream of the dam axis II-A. The Nala has the potential to bring heavy debris in the event of cloudburst and can cause damage to the stilling basin. Considering these factors it was decided to shift the Dam axis further $50 \mathrm{~m}$ upstream from axis IIA and new dam axis was referred as II-B. After detailed geological and geotechnical investigations and detailed design, where different components were laid out on the ground this Dam axis was again reviewed and the right edge of dam axis is rotated at an angle of 8.244 degrees downstream keeping the left edge same. The dam axis is referred as II-C and considered as final axis for planning. The site is geologically more suitable as rocks are exposed on the right abutment and in isolated patches on the left abutment on the surface. By rotating the dam axis, the dam crest length was reduced from $500 \mathrm{~m}$ to $429.5 \mathrm{~m}$ and it will reduce the excavation in the right bank for the construction of energy dissipater flip bucket, resulting in substantial reduction in excavation and concrete of dam, thereby reducing the cost and schedule of the project.

\section{Geology of the project area}

The bedrock encountered at the proposed Bunakha project site is represented largely by crystalline rocks of Thimphu Gneissic Complex belonging to upper amphibolite facies of metamorphism (Jangpangi, 1978; Gansser, 1983; Chowdhury, 1993, 1995; Mishra and Sanwal, 1994). The Thimphu Gneissic Complex, at site, is characterized by heterogeneous lithology consisting of foliated gneisses, streaky and banded gneisses, amphibolite gneisses. On the surface, in and around of dam area, garnetiferous foliated gneisses and banded gneisses have been mapped while drilling at this site encountered a sequence of foliated gneisses, banded gneisses, amphibolite gneisses and calc-silicate gneisses at different depths. At about $1.6 \mathrm{~km}$ upstream from the dam, there is a thrust contact (MCT-I) between the rocks of Thimphu (Thimphu Gneissic Complex) and Paro Formations (Bhargava, 1995, Koike, 2001, 2002). In general, formations (bedding/foliation S-1) show low to moderate $\left(10^{\circ}\right.$ to $\left.35^{\circ}\right)$ dip excepting in areas adjoining to fractures where local steep dips are noted. The rocks of Thimphu Formation at project site are folded into N-S trending antiform, dipping towards downstream side $\left(20^{\circ}-30^{\circ}\right)$ i.e. into the hill and plunging $\left(<19^{\circ}\right)$ southerly in the downstream. Endemic to folding these litho-units are traversed by multiple set of discontinuities viz. (i) parallel to axial plane forming valley parallel longitudinal joints (ii) steeply dipping conjugate system of diagonal joints and (iii) low angle conjugate discontinuities. In addition to these discontinuities, foliation discontinuities and shear-zones parallel to foliation have also been recorded. Geological map of this area compiled from the Geological Survey of India Map (1979-80); Bhargava (1995) and Koike $(2001,2002)$ is given in Fig. 2.

Major rocks exposed in the area are grey or grayish white foliated gneisses and banded gneisses having different structural characteristics and weathering grades (Nawani et al. 2011). Banded and foliated gneisses are always jointed and some variation in the pattern of jointing in the both type of rocks were measured. Along the foliation joints of banded gneisses, shearing is more dominating than foliation joints of the foliated gneisses. Medium grained banded gneisses are more jointed with rough undulating to rough planar surface while the surfaces of foliated gneisses are generally rough undulating. The rocks to be encountered during the excavation of dam foundation are banded gneisses, foliated gneisses, calcsilicate gneisses and bands of schistose quartzite. Based on petrographic studies, banded gneisses are found to be quartz, feldspar and muscovite rich having granular texture showing iron staining along the grain boundary of quartz. The shapes of grains are anhedral to subhedral. Foliated gneisses are dominated by quartz, feldspar and garnet with gneissic and schistose textures. The rock types present at Bunakha dam site have been classified into four units i.e. banded gneisses (BG), foliated gneisses (FG), alternate bands of gneisses with calcsilicate $(\mathrm{ABG})$ and schistose quartzite $(\mathrm{SQ})$.

\section{Field and laboratory studies}

\section{METHODOLOGY}

For an overall geological and geotechnical framework of foundation of a big dam, detailed site characterisation in terms of geology, hydrogeology, geophysical, geomechanics and geotechnical studies is required. During detailed site studies, geological mapping of outcrops, seismic refraction and seismic tomography surveys, core drilling and subsequent water pressure testing, exploratory drifting, deformability test in bore holes, in-situ shear test and laboratory testing were carried 


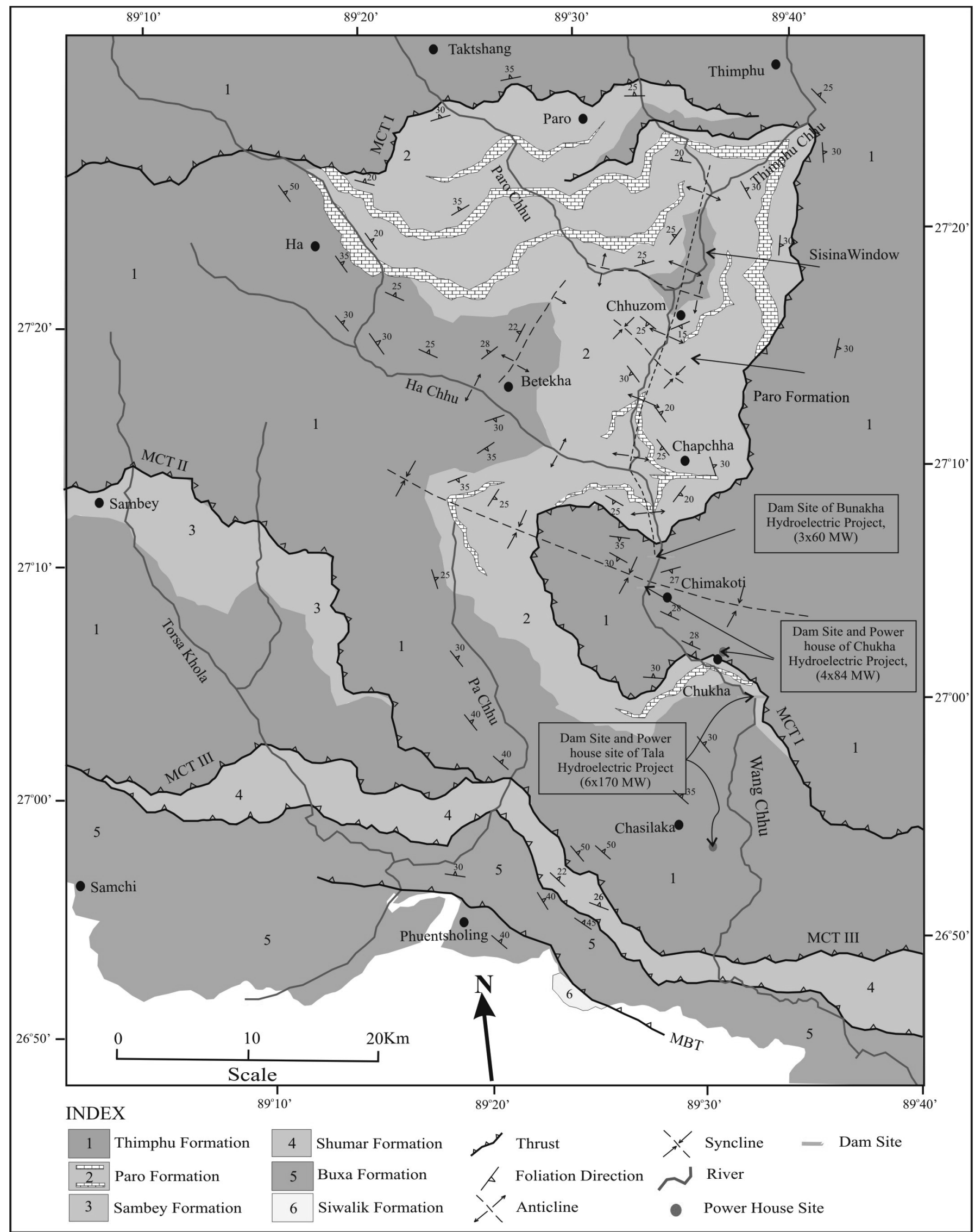

Fig. 2: Geology map of the Bunakha hydroelectric project and area around (After Geological Survey of India Map 1979-80; Bhargava 1995; Koike 2001, 2002). 
out. These investigations were conducted to collect required information regarding extent and thickness of overburden; type of underlying bedrock, its disposition and depth of weathering; P-wave velocities, permeability values and geomechanical properties of rock mass. Using the data generated at the Detailed Project Report (DPR), stage investigations from geological and structural mapping, subsurface explorations, in-situ and lab testing, location, alignment and dimension of the dam was finalised.

\section{Geological mapping}

Understanding the geological and structural setup of an area is required for economic and safe designing of a big dam. For the design of dam and its appurtenant structures, details examination of the lithological units and geological structures (faults, joints, shear zones, folds etc.), nature of the river valley and slopes and stability of river banks are particularly important. Moreover, foundation conditions and type of construction to suit the foundation structure are very important for techno-economic design of engineering structure. Engineering geological mapping was carried out on 1:1000 scale with $2 \mathrm{~m}$ contour intervals along the dam axis, $>300 \mathrm{~m}$ upstream and $>350 \mathrm{~m}$ downstream of dam axis and $300 \mathrm{~m}$ from the centre of river to the left and right abutments using the Total Station of LEICA having 0.5" accuracy (Fig. 3 ). The detailed mapping was done to delineate the distribution of the bed rock and alluvium/ overburden and to identify and study the structural features and also to evaluate the continuity of the structures consequent to stripping and treatment in the abutment foundation and from the point of view of reservoir leakage. Such mapping is also helpful for identifying the locations for exploratory drill holes, drifts and geophysical survey which has revealed that on the left abutment major area around the dam axis is covered by overburden dotted with isolated patches of bedrock outcrop and also moderate to dense vegetation while on the right abutment rock are exposed in the form of escarpment and area is moderate to dense forest covered.

The dam site has been located taking the advantage of the spur between Sirupa Chhu in the upstream $(304 \mathrm{~m})$ and Shirjalum Chhu in the downstream $(350 \mathrm{~m})$ to form left abutment and corresponding rock scarp on the other side of Wang Chhu as right abutment. Between the two tributaries, the river Wang Chhu flows in $\mathrm{S} 10^{\circ} \mathrm{E}$ direction and just at the confluence with Shirjalum Chhu where it cascades and takes abrupt southwesterly turn. The river forms a prominent 'boulder bar' on the left bank downstream of Sirupa Chhu and ill-defined river terrace in the right bank downstream of rock scarp. The talus cone formed by the Shirjalum Chhu is spectacular with respect to large house size blocks ( $3 \mathrm{~m} \times 3 \mathrm{~m}$ $\mathrm{x} 2 \mathrm{~m}$ ) lying at the margin of the cone.

On the left abutment, overburden which has generated as scree by retrogression of scarp/scarplets consists of large blocks (max. size $8 \mathrm{~m} \times 5 \mathrm{~m} \times 4 \mathrm{~m}$ ) of gneisses fixed in sandy/clayey matrix. The talus is underlain by foliated gneisses and banded gneisses with interlayers of weathered schistose bands or foliation parallel shear zones as confirmed by the exploratory drilling. The spur has limited rock exposures because of the talus cover on the gentle to moderate slope. The spur along the dam axis on the left abutment has definite break in slopes at different elevation. The left abutment rises above the river bed (El $1850 \mathrm{~m}$ ) at an angle of $30^{\circ}-40^{\circ}$ with break in slope approximately at El $1920 \mathrm{~m}$ and $1975 \mathrm{~m}$. After the prominent break at El $1920 \mathrm{~m}$, slope flattens to $20^{\circ}$ for a short distance before further rising at moderate angle of $55^{\circ}$. Overburden is characterised locally by well defined scars of old landslide and extensive creep of debris evident by inclined trees.

The right abutment is characterised by a rock scarp, it rises steeply at $>60^{\circ}$ angle above the river bed with minor break at El 1990m and El $1980 \mathrm{~m}$; further up the abutment has gentle angle of slope $\left(30^{\circ}\right)$ covered by considerable thickness of colluvial material. The scarp face exposes two litho-units viz. banded gneisses and foliated gneisses. At higher level, above RL 1940 m, the scarp face consists of banded gneisses with large boudins and stretched bands of quartzite. These units are characterised by foliation parallel shear zones. At the foot of the scarp the foliation $\left(\mathrm{S}_{1}\right)$ dips at $26^{\circ}-35^{\circ}$ in $\mathrm{N} 230^{\circ}$ direction, whereas in the upper reaches the foliation plane shows dips of the order of $250^{\circ} / 25^{\circ}$. Local changes in the foliation attitude are due to shearing and also in consonance to cross folding are witnessed. Gneisses in the right abutment are traversed by three sets of joints which have controlled the sculpturing of the scarp by geomorphic process. Intersections of different sets of joints form structural wedges, the lines of intersections are often followed by the gullies which bring down talus material depositing at the foot of the scarp which illustrates active slope failure. Slope instability is further indicated by fresh rockfall marks. The thickness of the overburden is of the order of 0.5$1.5 \mathrm{~m}$ on the right and $4-31 \mathrm{~m}$ on the left abutment, on the firm bedrocks as evaluated by the drill holes data.

At the dam axis, the river Wang Chhu flows through a $35 \mathrm{~m}$ wide gorge. The river has full bank flow with $7 \mathrm{~m}$ deep water channel. In vicinity of dam site, the river cascades through its bouldery course from El $1856 \mathrm{~m}$ in the upstream to El $1845 \mathrm{~m}$ in the downstream. There are scanty outcrop in vicinity in the river bed and engineering geological data was collected from these outcrop for ascertaining lithological and structural attributes of the river section. In addition, detailed subsurface exploratory plan by drilling and geophysical methods was outlined. Geological mapping around the dam site confirms that river Wang Chhu flows along a NW-SE trending antiformal fold axis with low southerly plunge. This has indications of steepening of the limbs near the core; gentle foliations outwards and away at higher elevation of the folded zone are noted. This was also substantiated by the exploratory drilling and cross-hole seismic tomography.

The discontinuities of the gniesses have shown the distinctive weathering characteristics. The banded gneisses stand out prominently with a marginal weathering (W-I, W-II) in contrast to foliated gneisses and calc-silicate bands show intensive weathering ranging from W-II to W-IV (ISRM, 1978). In the foundation of dam site on the left and right 
Table 2: Prominent joint sets developed in gneisses at the left and right abutments of dam site

\begin{tabular}{|c|c|c|c|c|c|c|c|c|}
\hline $\begin{array}{c}\text { Type of } \\
\text { Joint/ } \\
\text { Joint Set }\end{array}$ & $\begin{array}{c}\text { Dip } \\
\text { Direction/ } \\
\text { Dip } \\
\text { Amount }\end{array}$ & $\begin{array}{l}\text { Spacing } \\
(\mathrm{cm})\end{array}$ & $\begin{array}{l}\text { Persistence } \\
\text { (m) }\end{array}$ & Roughness & $\begin{array}{c}\text { Aperture } \\
(\mathbf{m m})\end{array}$ & Infilling & $\begin{array}{l}\text { Ground } \\
\text { Water }\end{array}$ & Remarks \\
\hline \multicolumn{9}{|c|}{ Left Abutment } \\
\hline $\begin{array}{l}\text { Foliation } \\
\qquad \mathrm{J} 1\end{array}$ & $\begin{array}{c}\mathrm{N} 125^{\circ}- \\
\mathrm{N} 140^{\circ} / 18^{\circ} \\
-44^{\circ}\end{array}$ & $10-50$ & $>20$ & $\begin{array}{l}\text { Rough } \\
\text { undulating - } \\
\text { rough planar }\end{array}$ & $\begin{array}{l}\text { Tight to } \\
11\end{array}$ & none & Dry & $\begin{array}{l}\text { Shear zones are some times } \\
\text { formed along this joint. } \\
\text { Foliations are dipping } \\
\text { toward downstream site } \\
\text { i.e. inside the hill. Jv is } 11 .\end{array}$ \\
\hline $\begin{array}{l}\text { Inclined } \\
\mathrm{J} 2\end{array}$ & $\begin{array}{l}\mathrm{N} 315^{\circ}- \\
330^{\circ} / 23^{\circ} \\
-45^{\circ}\end{array}$ & $20-30$ & $>3$ & $\begin{array}{l}\text { Rough } \\
\text { undulating }\end{array}$ & $\begin{array}{l}\text { Tight to } \\
30\end{array}$ & none & Dry & $\begin{array}{l}\text { Joints are perpendicular to } \\
\text { dam axis. }\end{array}$ \\
\hline $\begin{array}{c}\text { Inclined } \\
\mathrm{J} 3\end{array}$ & $\begin{array}{l}\mathrm{N} 234^{\circ}- \\
245^{\circ} / 70^{\circ} \\
-80^{\circ}\end{array}$ & $40-100$ & $1.5-2.0$ & $\begin{array}{l}\text { Rough } \\
\text { undulating }\end{array}$ & Tight & none & Dry & $\begin{array}{l}\text { Joints dipping toward } \\
\text { valley, often control the } \\
\text { valley slope. }\end{array}$ \\
\hline $\begin{array}{l}\text { Vertical } \\
\mathrm{J} 4\end{array}$ & $\begin{array}{c}\mathrm{N} 260^{\circ}-275^{\circ} \\
/ \mathrm{V}\end{array}$ & $10-120$ & $1.3-2.5$ & $\begin{array}{l}\text { Rough } \\
\text { undulating }\end{array}$ & Tight to 8 & none & Dry & $\begin{array}{l}\text { Vertical joint, for vertical } \\
\text { joint strike is given }\end{array}$ \\
\hline \multicolumn{9}{|c|}{ Right Abutment } \\
\hline $\begin{array}{l}\text { Foliation } \\
\qquad \mathrm{J} 1\end{array}$ & $\begin{array}{l}\mathrm{N} 205^{\circ}- \\
255^{\circ} / 25^{\circ} \\
-40^{\circ}\end{array}$ & $6-63$ & $>20$ & $\begin{array}{l}\text { Rough } \\
\text { undulating - } \\
\text { rough planar }\end{array}$ & $\begin{array}{l}\text { Tight to } \\
30\end{array}$ & $\begin{array}{c}\text { Sheared } \\
\text { gaugy } \\
\text { material }\end{array}$ & Dry & $\begin{array}{l}\text { Minor shearing along } \\
\text { the foliation planes. } \\
\text { Foliations dipping toward } \\
\text { downstream site i.e. inside } \\
\text { the slope. }\end{array}$ \\
\hline $\begin{array}{c}\text { Inclined } \\
\mathrm{J} 2\end{array}$ & $\begin{array}{l}\mathrm{N} 030^{\circ}- \\
055^{\circ} / 44^{\circ} \\
-60^{\circ}\end{array}$ & $30-63$ & $1.15-2.5$ & $\begin{array}{l}\text { Rough } \\
\text { undulating }\end{array}$ & $\begin{array}{l}\text { Tight to } \\
15\end{array}$ & None & Dry & $\begin{array}{l}\text { Joint dipping toward } \\
\text { valley, often controls the } \\
\text { valley slope. }\end{array}$ \\
\hline $\begin{array}{l}\text { Vertical } \\
\text { J3 }\end{array}$ & $\begin{array}{c}\mathrm{N} 245^{\circ}-260^{\circ} \\
/ \mathrm{V}\end{array}$ & $75-94$ & $1.0-2.5$ & $\begin{array}{l}\text { Smooth } \\
\text { planar }\end{array}$ & Tight to 6 & None & Dry & $\begin{array}{l}\text { Vertical joint, for vertical } \\
\text { joint strike is given }\end{array}$ \\
\hline
\end{tabular}

abutments, four and three sets respectively of discontinuities are mostly inclined to vertical in nature are prominent (Table 2). The geological details available from the geological plan at the dam site and on the basis of exploratory drill holes data, drift data and geophysical profiling, geological section was developed on the observed section along the dam axis is given in Figure 4. Probable lines defining weathering and destressed limits are indicated in the geological section.

\section{Geophysical investigations}

Geophysical investigations comprising seismic refraction survey along three lines at different elevations i.e. on the left abutment of dam and cross hole seismic tomography across river section approx. $39 \mathrm{~m} \mathrm{u} / \mathrm{s}$ from the dam axis were carried out by National Institute of Rock Mechanics (Jha et al. 2011) (Fig. 3). Due to unfavourable terrain condition geophysical profiling was not done at the right abutment of the dam site. Subsurface investigations by seismic refraction survey was extended up to $70 \mathrm{~m}$ depth with a view to determine the depth of overburden and its trend along the line of survey, map the profile of hard rock layer and its nature and indicate geological anomalies, if any. Subsurface strata have been grouped under different categories as per the range of seismic velocity. Seismic velocity ranges between $500-1250 \mathrm{~m} / \mathrm{sec}$ has been grouped under top soil/overburden layer, $1250-2000 \mathrm{~m} / \mathrm{sec}$ under weathered rock, $2000-3500 \mathrm{~m} / \mathrm{sec}$ under jointed/destressed rock mass and more than $3500 \mathrm{~m} / \mathrm{sec}$ under hard rock layer. The section line along the profile- 1 (above the crest level of dam) a weak zone is observed between $16-60 \mathrm{~m}$ chainage at a depth of $70 \mathrm{~m}$ i.e. El $1955 \mathrm{~m}$. In other two profiles geological anomaly was not observed. As per the seismic refraction survey the average depth of sound rock along the left abutment may be between $18-58 \mathrm{~m}$. The highlights of the subsurface seismic refraction survey are given in Table 3.

Cross-hole seismic tomography was done across two boreholes (DH-15 and DH-17) across the river banks with a view to determine the trend of hard rock within the river bed, examines the likely trend of anticline within the dam foundation and presence of geological anomalies, if any. River section has been grouped under different categories as per the range of seismic velocity. Seismic velocity up to $3750 \mathrm{~m} / \mathrm{sec}$ has been grouped under river borne material containing big boulders, $3750-4000 \mathrm{~m} / \mathrm{sec}$ under destressed rock mass and more than $4000 \mathrm{~m} / \mathrm{sec}$ under hard rock layer with few joints. As regards to the seismic tomography, the velocity section indicates that in an average up to $26 \mathrm{~m}$ depth river borne material is present. 


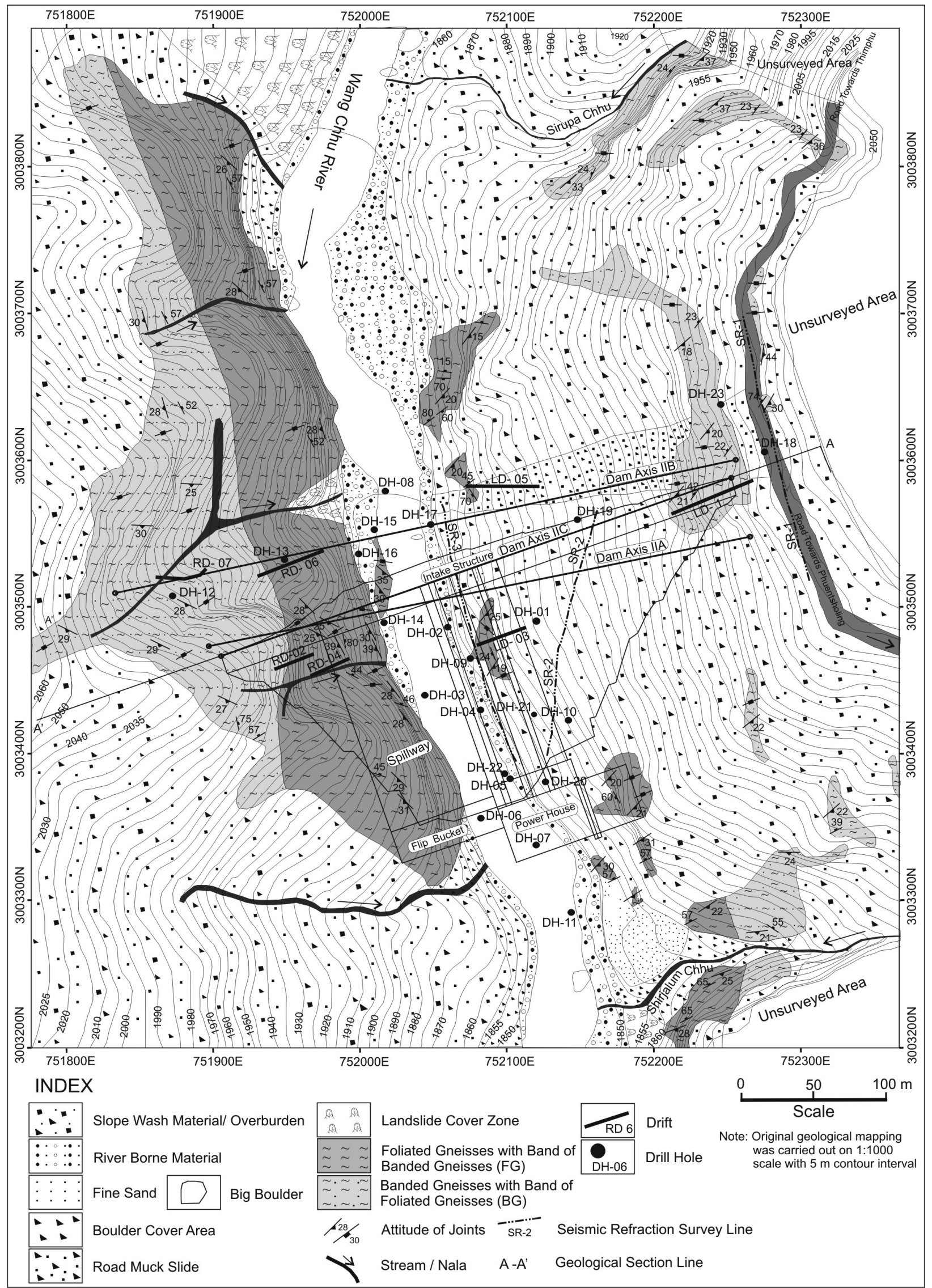

Fig. 3: Geological plan map of the dam area. 


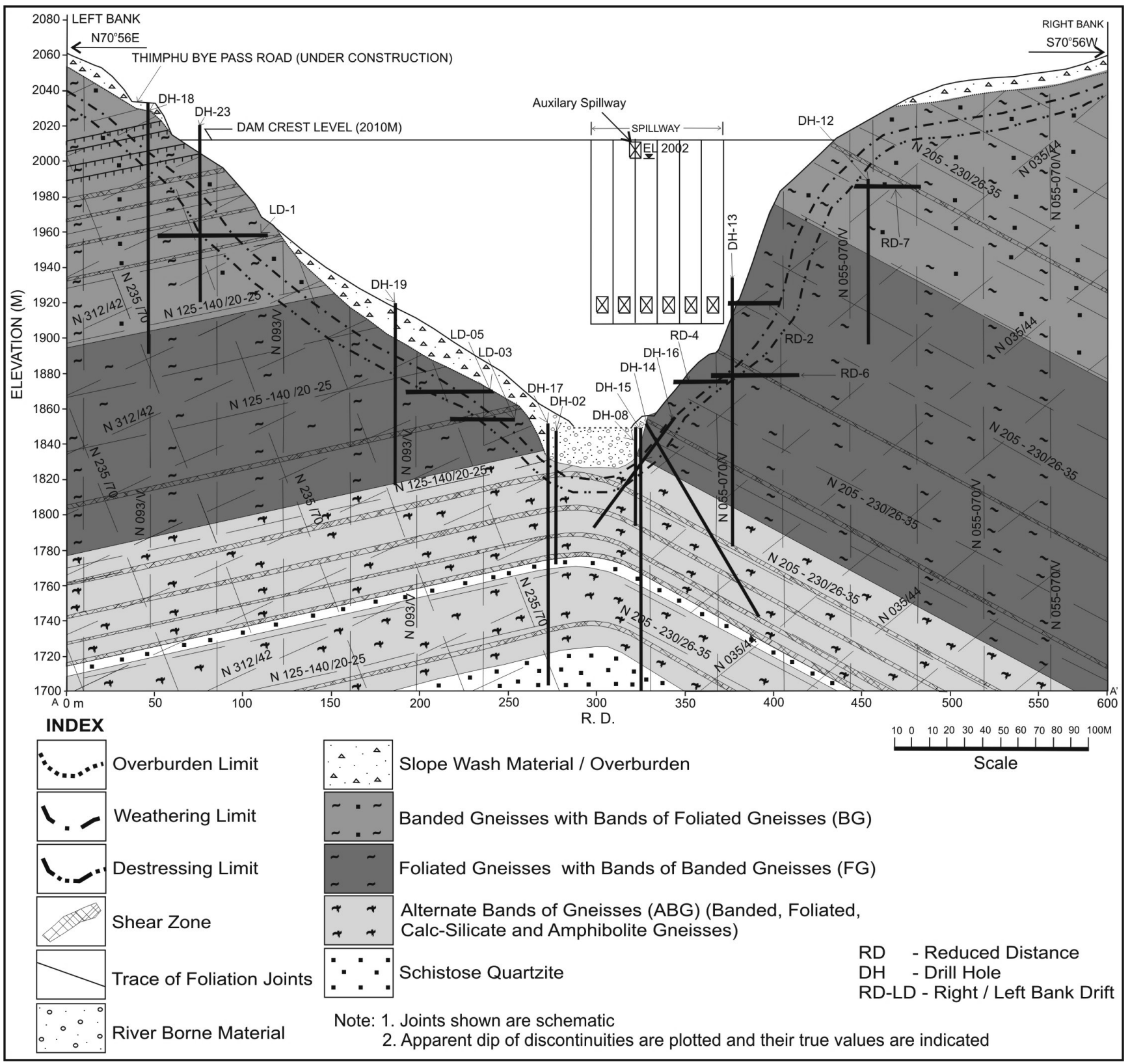

Fig. 4: Geological section along the dam axis.

Layers of rock mass with a seismic velocity between 3750 $4000 \mathrm{~m} / \mathrm{s}$ may constitute the continuation of destressed layer i.e. up to El $1813 \mathrm{~m}$ on the left bank and El $1818 \mathrm{~m}$ on the right side of the river channel. On the basis of this section stripping limit can be marked at El $1813 \mathrm{~m}$. Based on low seismic velocity $(3750 \mathrm{~m} / \mathrm{sec})$, below El $1813 \mathrm{~m}$ weak plane trending in NW-SE was observed and this could be the trend of anticlinal axis.

\section{Exploratory Drilling}

Based on geological and geophysical data, the exploratory drilling (vertical and inclined) were planned at dam site with the objective of determining the quality of the rock mass likely to be encountered during the excavation, depth of overburden, depth of weathering/destressing, existence of shear zone/weak zone and rock types at foundation level. Drilling was advanced by rotary core drilling method using double tube core barrels. A double tube core barrel and Nx sized bits are used for drilling and recovering rock cores but triple tube core barrel was also used in low core recovery zones. The dam site has been explored by eleven drill holes, three on the right bank (DH-12, DH-13 and DH-14) of Wang Chhu River, four on the left bank (DH-17, DH-18, DH-19 and DH-23) and four in the river section area (DH-02, DH-08, DH-15 and DH-16). Depth of boreholes is varying from $51.82 \mathrm{~m}$ to $150.0 \mathrm{~m}$ i.e. below the existing grade level to assess the subsurface conditions. The cores recovered from these drill holes were examined and geologically logged and their details are given in Table 4 . In bed 
Table 3: Highlights of the subsurface seismic refraction survey

\begin{tabular}{|c|c|c|c|c|c|}
\hline $\begin{array}{l}\text { Line } \\
\text { ID \& } \\
\text { Length }\end{array}$ & Elevation (m) & $\begin{array}{l}\text { Depth of } \\
\text { Top Soil } \\
\text { Layer }\end{array}$ & \begin{tabular}{|c|} 
Depth of \\
Weathered \\
Rock \\
Layer
\end{tabular} & \begin{tabular}{|c|} 
Depth of \\
Destressed \\
Rock \\
Layer \\
\end{tabular} & Observation from seismic velocity section \\
\hline $\begin{array}{l}\text { Profile-1 } \\
184 \mathrm{~m}\end{array}$ & 2034.50 & $\begin{array}{l}6.5 \mathrm{~m} \\
21.0 \mathrm{~m}\end{array}$ to & $\begin{array}{l}12.0 \mathrm{~m} \\
32.5 \mathrm{~m}\end{array}$ to & $\begin{array}{ll}28.5 \mathrm{~m} & \text { to } \\
58.0 \mathrm{~m}\end{array}$ & $\begin{array}{l}\text { Top soil layer is } 11 \mathrm{~m} \text { thick near borehole (DH-18) location, } \\
\text { hard rock layer has a deceptive trend, marked by several } \\
\text { troughs, a weak zone is observed between } 16-60 \mathrm{~m} \text { chainage } \\
\text { below El } 1994.5 \mathrm{~m} \text {. The stripping limit along this section } \\
\text { line will be varying from } 26 \mathrm{~m} \text { to } 54 \mathrm{~m} \text {. }\end{array}$ \\
\hline $\begin{array}{l}\text { Profile-2 } \\
184 \mathrm{~m}\end{array}$ & $\begin{array}{l}1928.00 \mathrm{~m} \\
\text { towards the NE } \\
\text { side, } 1867.00 \\
\text { m towards SW } \\
\text { side } \\
\end{array}$ & $\begin{array}{l}5.0 \mathrm{~m} \\
17.5 \mathrm{~m}\end{array}$ to & $\begin{array}{l}10.5 \mathrm{~m} \\
24.0 \mathrm{~m}\end{array}$ to & $\begin{array}{ll}18.0 \mathrm{~m} & \text { to } \\
36.0 \mathrm{~m}\end{array}$ & $\begin{array}{l}\text { Hard rock layer is dipping at } 20^{\circ} \text { following the trend of } \\
\text { surface slope. The stripping limit along this section line will } \\
\text { be varying from } 14 \mathrm{~m} \text { to } 33 \mathrm{~m} \text {. }\end{array}$ \\
\hline $\begin{array}{l}\text { Profile-3 } \\
184 m\end{array}$ & $1860.20 \mathrm{~m}$ & $\begin{array}{l}2.20 \mathrm{~m} \text { to } \\
15.0 \mathrm{~m}\end{array}$ & $\begin{array}{ll}10.1 \mathrm{~m} & \text { to } \\
27.5 \mathrm{~m}\end{array}$ & $\begin{array}{ll}21.5 \mathrm{~m} & \text { to } \\
38.0 \mathrm{~m}\end{array}$ & $\begin{array}{l}\text { Hard rock is consistent at an av. } 29 \mathrm{~m} \text { depth (Vp } 3500 \\
\mathrm{~m} / \mathrm{sec} \text { ). The stripping limit along this section line will be } \\
\text { varying from } 18 \mathrm{~m} \text { to } 34 \mathrm{~m} \text {. }\end{array}$ \\
\hline
\end{tabular}

rock portion the poor core recovery is ascribed to the presence of schistose interlayers and shear zones parallel to foliation planes. Nil core recovery may be due to the inclination of hole with respect to the foliation of rock or due to the technique of drilling.

\section{In-situ Permeability Tests}

Analysis of a dam foundation requires knowledge of the hydrostatic pressure distribution in the foundation. The extents of grouting and cut-off depths required in dam foundation are directly related to the hydraulic conductivity (permeability) of the rock masses involved. Permeability is controlled by the characteristics of the rock type, jointing systems, the shears and fissures, fault zones and by solution cavities in the rock. Water percolation tests were conducted in selected sections of the boreholes, at increasing and decreasing cycle of pressure, to determine rock mass permeability values. Water permeability tests were carried out by double packer method in the bedrock portion. 284 numbers permeability tests were conducted at dam site. The lugeon values recorded from the drill holes of left abutment are moderate to high indicating that few partially open /many open discontinuities are present in the rock mass. Percolation tests show nature of flow as dilation, laminar flow, turbulent, void filling, washout and hydraulic fracturing. From the right abutment drill holes the lugeon values recorded are very low to medium indicating that some open discontinuities are present in the rock mass. Percolation tests show nature of flow as dilation, void filling, washout, hydraulic fracturing, turbulent and laminar flow. From the four drill holes (DH02, DH-08, DH-15 \& DH-16), drilled in the river channel or nearby, lugeon values recorded are low to medium indication that some open discontinuities are present in the rock mass. Percolation tests show nature of flow as dilation, void filling and turbulent flow.

\section{Exploratory Drifts}

Seven drifts, three on the left (LD-1, LD-3 \& LD-5) and four on right (RD-2, RD-4, RD-6 \& RD-7) abutments of dam site were excavated to explore the actual geological conditions on the either abutments of dam location by identifying rock types, structural discontinuities, shear zones, weak zones and other adverse geological features. D-shaped drifts of size $1.8 \mathrm{~m}(\mathrm{~W}) \times 2.1 \mathrm{~m}(\mathrm{H})$, lengths varying from 30 to 61 $\mathrm{m}$ were excavated by drill and blast method. The drifts were properly cleaned and marking of chainage at $1 \mathrm{~m}$ interval on side wall was done before geological logging. Drifts were geologically logged on 1:100 scale for the slumping nature of rock mass and to evaluate stripping limits. Discontinuities were measured, weathering grade and zones of destressing and glide planes have been identified. The general description of rock types encountered in the drifts is given in Table 5 . Rock mass classification was done using Q and RMR systems (Table 6). Geological Strength Index (GSI) has been estimated from RMR (Bieniawski 1989) rock mass classification. RMR method can be used when $\mathrm{RMR}_{89} \geq 23$ to estimate GSI.

\section{Deformability Test}

Although the dam is considered to be homogeneous, elastic and isotropic, its foundation is generally heterogeneous, inelastic and anisotropic. These characteristics of the foundation have significant effects on the deformation moduli of the foundation. Deformability tests using High Pressure Dilatometer (HPD) were conducted up to $20 \mathrm{MPa}$ pressure in rock at various depths in four boreholes to estimate insitu deformation modulus and lateral stress and test result are summarized in Table 7. The deformation modulus and shear modulus are determined for banded and foliated gneisses which are present at the foundation. The rock has withstood the pressure in excess of $150 \mathrm{~kg} / \mathrm{cm}^{2}$ and limit pressure is not achieved. The relatively lower values of deformation modulus and shear modulus achieved for DH-19 and DH-23 are due to poor core recovery, nil RQD and weathered rock mass which indicate the rock mass to be in a poor state. In DH-12, deformation and shear values are high due to excellent core recovery, fair RQD and fresh rock mass and are indicative of relatively better quality of rock mass. 
"ू.
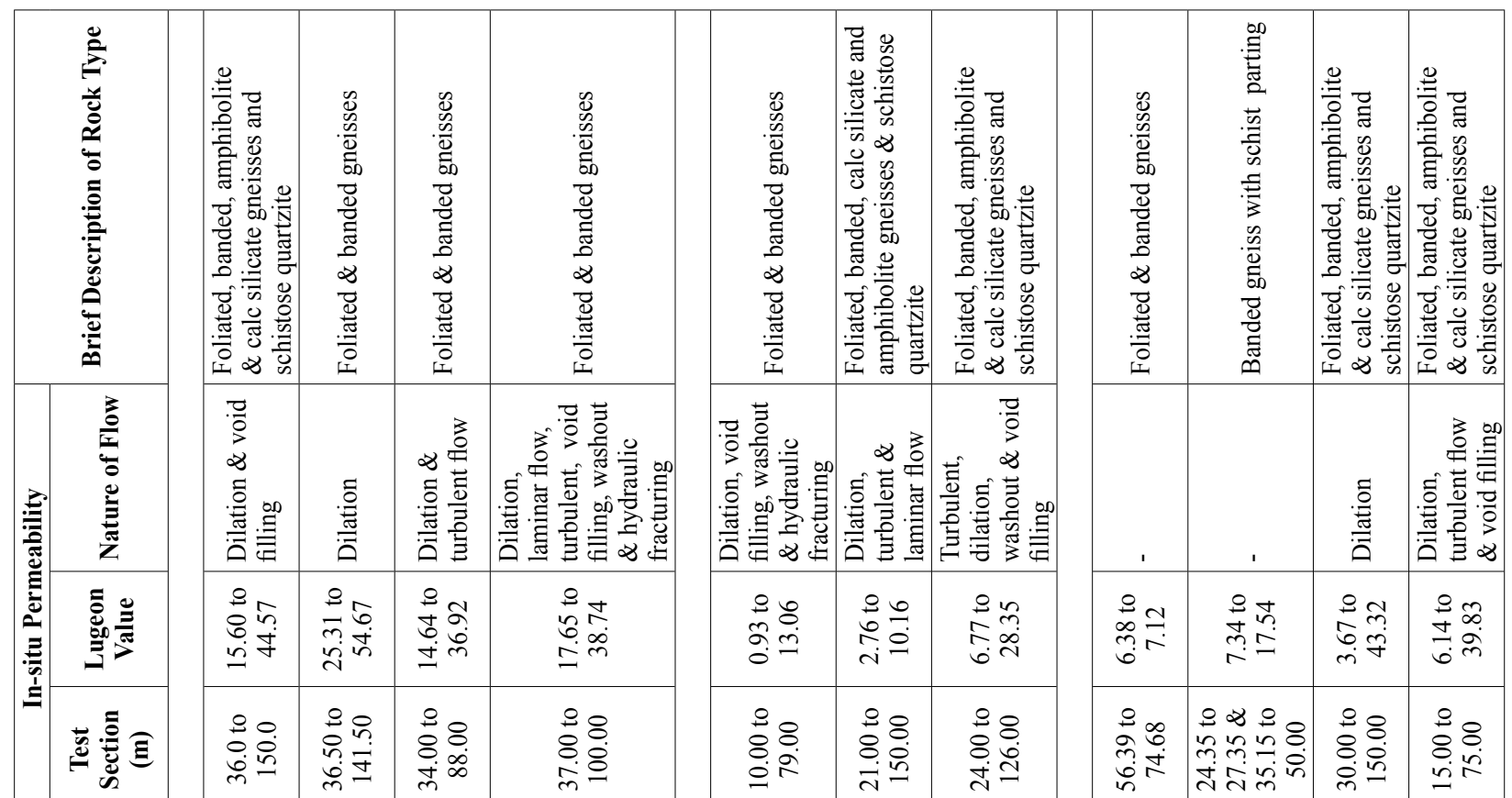

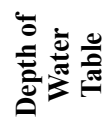

\begin{tabular}{|c|c|c|c|}
\hline$\stackrel{\Xi}{\stackrel{\Xi}{-}}$ & 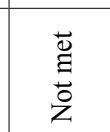 & 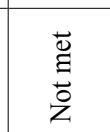 & $\begin{array}{l}\stackrel{\Xi}{\Xi} \\
\stackrel{\Xi}{\Delta} \\
Z\end{array}$ \\
\hline 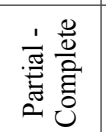 & 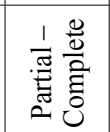 & 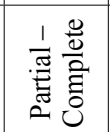 & 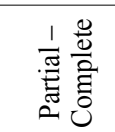 \\
\hline 8 & $=8$ & $=\stackrel{0}{\circ}$ & $=8$ \\
\hline
\end{tabular}

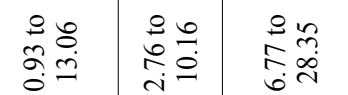

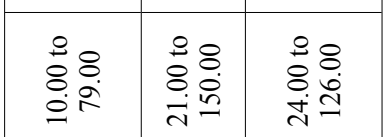

\begin{tabular}{|c|c|c|}
\hline 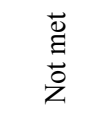 & 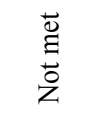 & 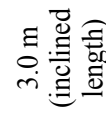 \\
\hline 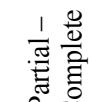 & 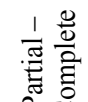 & 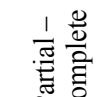 \\
\hline
\end{tabular}

\begin{tabular}{|c|c|c|c|}
\hline ' & & $\begin{array}{l}\Xi \\
\vdots \\
0 \\
0\end{array}$ & 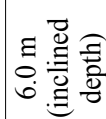 \\
\hline 版 & 㖊 & 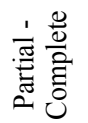 & 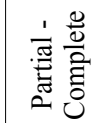 \\
\hline$\overline{\bar{z}} \underset{\dot{T}}{8}$ & 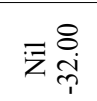 & 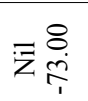 & $\overline{\bar{z}} \stackrel{8}{\infty}$ \\
\hline
\end{tabular}

递高

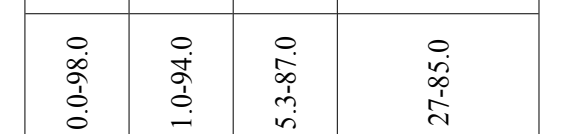

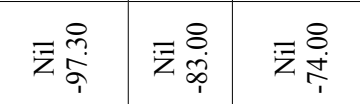

\begin{tabular}{|c|c|c|}
\hline$\stackrel{8}{8}$ & $\dot{8}$ & F́ \\
\hline ¿े & $\stackrel{g}{g}$ & 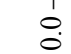 \\
\hline
\end{tabular}

\begin{tabular}{|c|c|c|c|}
\hline $\begin{array}{l}\stackrel{\leftrightarrow}{0} \\
\dot{1} \\
0\end{array}$ & $\begin{array}{l}0 \\
\dot{\phi} \\
\dot{0} \\
0 \\
0\end{array}$ & $\begin{array}{l}0 \\
\stackrel{8}{0} \\
\frac{1}{1} \\
\dot{m}\end{array}$ & $\begin{array}{l}\text { i } \\
\text { dì } \\
\text { in }\end{array}$ \\
\hline
\end{tabular}

\begin{tabular}{|c|c|c|c|c|c|}
\hline \multicolumn{2}{|l|}{ 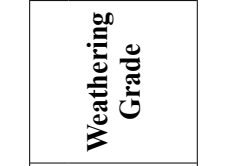 } & $\begin{array}{l}2 \\
3 \\
1 \\
1 \\
3 \\
3\end{array}$ & $\begin{array}{l}3 \\
3 \\
1 \\
\frac{1}{3}\end{array}$ & $\begin{array}{l}\Rightarrow \\
1 \\
1 \\
\frac{1}{3} \\
3\end{array}$ & $\begin{array}{l}3 \\
3 \\
\frac{1}{3} \\
3\end{array}$ \\
\hline 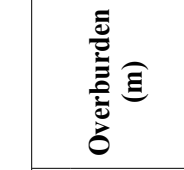 & & $\frac{8}{\dot{m}}$ & $\begin{array}{l}8 \\
\dot{0} \\
-1\end{array}$ & $\stackrel{8}{\stackrel{\Xi}{\Xi}}$ & $\underset{+}{\stackrel{\leftrightarrow}{+}}$ \\
\hline 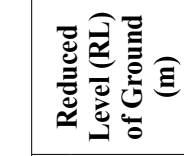 & & $\begin{array}{l}\hat{b} \\
\stackrel{-}{5} \\
\infty \\
\infty\end{array}$ & $\begin{array}{l}8 \\
\text { i. } \\
\widetilde{\hat{~}}\end{array}$ & $\begin{array}{l}\tilde{\sigma} \\
\infty \\
\stackrel{\infty}{a}\end{array}$ & $\begin{array}{l}\stackrel{n}{2} \\
\stackrel{2}{\grave{1}}\end{array}$ \\
\hline 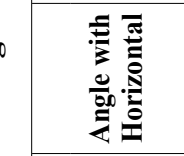 & & 8 & 8 & 8 & 8 \\
\hline 产 & & 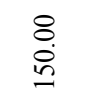 & 足 & 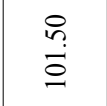 & $\begin{array}{l}8 \\
\dot{8}\end{array}$ \\
\hline 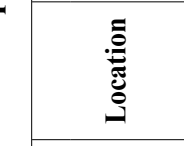 & 咅 & 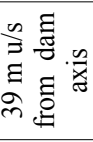 & 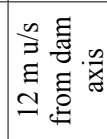 & 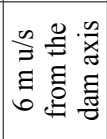 & 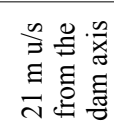 \\
\hline 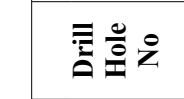 & 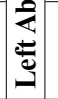 & 竞 & $\stackrel{\dot{\prime}}{\vec{a}} \stackrel{\infty}{-}$ & 高 & 岕 \\
\hline
\end{tabular}

\begin{tabular}{|c|c|c|}
\hline 率 & $\frac{F}{3}$ & $\sum_{1}^{3}$ \\
\hline$\frac{1}{3}$ & $\frac{1}{3}$ & $\frac{1}{3}$ \\
\hline & 0 & 丞 \\
\hline
\end{tabular}

\begin{tabular}{|c|c|c|c|}
\hline 具 & 寻 & $\vec{z}$ & 罗 \\
\hline$\frac{1}{3}$ & $\frac{1}{3}$ & $\frac{1}{3}$ & $\frac{1}{3}$ \\
\hline
\end{tabular}


Table 5: General description of rock encountered in the drifts

\begin{tabular}{|c|c|}
\hline $\begin{array}{l}\text { Drift No. and } \\
\text { Total Length }\end{array}$ & Description \\
\hline LD-1 and $61.00 \mathrm{~m}$ & $\begin{array}{l}\text { Excavated at left abutment, portal at } 7.16 \mathrm{~m} \text { downstream of the dam axis at R.L. } 1958.00 \mathrm{~m} \text {. Rock types } \\
\text { mapped are banded gneiss with interlayers of foliated gneiss and schist bands. The general foliation trend } \\
\text { is N } 30^{\circ} \mathrm{E}-\mathrm{S} 30^{\circ} \mathrm{W} \text { with south-easterly dip. Shearing parallel to foliation joint is common. Valley dipping } \\
\text { joints are observed up to } 44 \mathrm{~m} \text { reach. The destressing limit is marked at } 44 \mathrm{~m} \text { however stripping limit is } \\
\text { kept at } 39 \mathrm{~m} \text {. }\end{array}$ \\
\hline LD-3 and 36 & $\begin{array}{l}\text { At left abutment, portal at } 49.24 \mathrm{~m} \mathrm{~d} / \mathrm{s} \text { of the dam axis at R.L. } 1857.42 \mathrm{~m} \text { and excavated in N70 E direction. } \\
\text { Rock types exposed are foliated gneiss with bands of banded gneiss and minor biotite schist bands. The } \\
\text { destressing limit is marked at } 31 \mathrm{~m} \text { however stripping limit is kept at } 27 \mathrm{~m} \text {. Foliation parallel shear zones } \\
\text { with clayey gouge is common. }\end{array}$ \\
\hline LD-5 and $50.00 \mathrm{~m}$ & $\begin{array}{l}\text { At left abutment, portal at } 44.79 \mathrm{~m} \mathrm{u} / \mathrm{s} \text { of dam axis at R.L. } 1869.455 \mathrm{~m} \text {. Rock types mapped are foliated } \\
\text { gneisses with bands of banded gneisses The destressing limit is marked at } 30 \mathrm{~m} \text { however stripping limit is } \\
\text { kept at } 28 \mathrm{~m} \text {. The rocks are moderately weathered to fresh and throughout the drift groundwater condition } \\
\text { was dry. }\end{array}$ \\
\hline $\mathrm{RD}-2$ and & $\begin{array}{l}\text { At right abutment, portal at } 19.49 \mathrm{~m} \mathrm{~d} / \mathrm{s} \text { of the dam axis at R.L. } 1917.00 \mathrm{~m} \text {. Rock types mapped are foliated } \\
\text { gneiss with bands of banded gneiss. The general foliation trend is } \mathrm{N} 30^{\circ} \mathrm{W}-\mathrm{S} 30^{\circ} \mathrm{E} \text { dipping } 25^{\circ} \text { in } \mathrm{S}^{\circ} \mathrm{W} \\
\text { direction. The destressing limit is marked at } 30 \mathrm{~m} \text { however stripping limit is kept at } 26 \mathrm{~m} .\end{array}$ \\
\hline $\mathrm{RD}-4$ & $\begin{array}{l}\text { At right abutment, portal at } 31.70 \mathrm{~m} \mathrm{~d} / \mathrm{s} \text { of the dam axis at R.L. } 1874.30 \mathrm{~m} \text { and excavated in } \mathrm{N} 67^{\circ} \mathrm{W} \\
\text { direction. Rock types mapped are foliated gneiss and banded gneiss. The destressing limit is marked at } 30 \\
\mathrm{~m} \text { however stripping limit is kept at } 26 \mathrm{~m} \text {. }\end{array}$ \\
\hline RD-6 & $\begin{array}{l}\text { At right abutment and portal at } 42.31 \mathrm{~m} \mathrm{u} / \mathrm{s} \text { of dam axis at R.L. } 1875.736 \mathrm{~m} \text {. The rock types mapped are } \\
\text { thinly foliated biotite gneiss with boudinage of quartz. The destressing limit is marked at } 19 \mathrm{~m} \text { however } \\
\text { stripping limit is kept at } 18 \mathrm{~m} .\end{array}$ \\
\hline RD-7 and $37.5 \mathrm{~m}$ & $\begin{array}{l}\text { At right abutment, portal at } 54.45 \mathrm{~m} \mathrm{u} / \mathrm{s} \text { of dam axis at R.L. } 1986.45 \mathrm{~m} \text {. Banded gneiss with boudins of } \\
\text { quartz and minor bands of foliated gneiss are mapped. The destressing limit is marked at } 11 \mathrm{~m} \text { however } \\
\text { stripping limit is kept at } 10 \mathrm{~m} \text {. }\end{array}$ \\
\hline
\end{tabular}

\section{In-situ Shear Test}

Resistance to shear within the foundation and between the dam and its foundation depends upon the cohesion and internal friction inherent in the foundation materials and in the bond between concrete and rock at the contact with the dam. These properties were determined from laboratory and in-situ tests. In-situ shear test for determining shear strength parameter of rock to rock and concrete to rock interface were conducted inside the four drifts. The objective of in-situ shear test was to determine the in-situ peak and residual direct shear strength of a discontinuity on the interface between concrete and rock foundation. Rock to rock and rock to concrete tests were conducted. For each test, five numbers of test block were prepared and tested at differed load. Rock surfaces were prepared by careful manual chieselling and concrete/rock blocks of size $70 \times 70 \times 30 \mathrm{~cm}$ were prepared. The concrete mix used for the preparation of concrete blocks was $1: 2$ : 4 (cement : coarse aggregate : fine aggregates). The blocks were allowed to cure for 28 days. A concrete block cast on rock surface or block of rock intact with the rock mass was subjected to a normal load and sheared under increasing shear force on a predetermined plane of shear. The displacements of the block in the direction of these forces were recorded with the shear resistance, for estimating the peak shear resistance of the joint/interface as the case may be. The normal and shearing loads were applied by means of hydraulic jacks and deformations were recorded by means of dial gauges having a least count of $0.01 \mathrm{~mm}$. The reactions were taken from roof and sides of drift. The tests were conducted in saturated conditions by saturating the interface to be sheared by submerging in water for minimum of 24 hours. The shearing force was applied from upstream to downstream in all the in-situ shear tests performed. Test results are summarized in Table 8. The average angle of fraction and cohesion are $43^{\circ}$ and $0.56 \mathrm{~kg} / \mathrm{cm}^{2}$ for peak shear stress values respectively. The angle of friction shows that there is a good bond on concrete rock interface. The shearing took place at the interface of rock and concrete for all the blocks.

\section{Laboratory Testing}

Selected rock core samples from the boreholes drilled along the left and right abutment and river section of dam site were tested for physico-mechanical properties of rocks in the laboratory. Because the foundation rock is non-homogeneous, tests to obtain physico-mechanical values were determined for each type of rock in the loaded portion of the foundation. The engineering properties given in Table 9 were evaluated 
Table 6. Rock mass classification of drifts rock type

\begin{tabular}{|c|c|c|c|c|c|c|c|}
\hline \multirow[b]{2}{*}{ Rock Type } & \multirow[b]{2}{*}{$\begin{array}{l}\text { Reduced } \\
\text { Distance } \\
\text { (RD) (m) }\end{array}$} & \multirow[b]{2}{*}{$\begin{array}{l}\text { Joint Set } \\
\text { Number }\end{array}$} & \multirow[b]{2}{*}{$\begin{array}{l}\text { Weathering } \\
\text { Grade }\end{array}$} & \multirow[b]{2}{*}{$\begin{array}{c}\mathbf{Q} \\
\text { Values } \\
\text { (Av.) }\end{array}$} & \multicolumn{2}{|c|}{ RMR } & \multirow{2}{*}{$\begin{array}{c}\text { Geological } \\
\text { Strength Index } \\
\text { (GSI) (From } \\
\text { RMR 89) (Av.) }\end{array}$} \\
\hline & & & & & $\begin{array}{l}\text { Values } \\
\text { (Range) }\end{array}$ & Class & \\
\hline \multicolumn{8}{|l|}{ LD-1 } \\
\hline Banded \& foliated gneisses & $0.0-15.0$ & \begin{tabular}{ll|} 
Three & plus \\
random
\end{tabular} & W-I to W-II & 0.94 & $38-51$ & III-IV & 41 \\
\hline $\begin{array}{l}\text { Banded gneiss with schist } \\
\text { interlayer }\end{array}$ & $15.0-37.0$ & Two plus random & W-I to W-III & 1.56 & $39-57$ & III-IV & 45 \\
\hline Banded \& foliated gneisses & $37.0-53.0$ & Two plus random & W-I to W-II & 1.99 & $47-59$ & III & 48 \\
\hline Banded gneiss & $53.0-61.0$ & One plus random & W-I to W-II & 2.05 & $40-58$ & III-IV & 46 \\
\hline \multicolumn{8}{|l|}{ LD-3 } \\
\hline $\begin{array}{l}\text { Foliated gneiss with schist } \\
\text { interlayer }\end{array}$ & $0.0-4.5$ & Two plus random & W-III & 0.63 & $39-43$ & III-IV & 36 \\
\hline $\begin{array}{l}\text { Foliated gneiss with schist } \\
\text { interlayer }\end{array}$ & $4.5-15.0$ & Two plus random & W-II & 2.92 & $53-60$ & III & 51 \\
\hline $\begin{array}{l}\text { Foliated gneiss with bands of } \\
\text { banded gneiss }\end{array}$ & $15.0-27.0$ & Three & W-II to W-IV & 0.68 & $38-48$ & III-IV & 37 \\
\hline Banded gneiss & $27.0-36.0$ & Two plus random & W-I to W-II & 3.85 & $56-62$ & II-III & 53 \\
\hline \multicolumn{8}{|l|}{ LD-5 } \\
\hline Foliated gneiss & $0.0-10.0$ & One plus random & W-I to W-II & 3.7 & $52-64$ & II-III & 52 \\
\hline $\begin{array}{l}\text { Foliated gneiss with bands of } \\
\text { banded gneiss }\end{array}$ & $10.0-37.0$ & Two plus random & W-I to W-III & 2.7 & $45-64$ & II-III & 48 \\
\hline Foliated gneiss & $37.0-50.0$ & Two plus random & W-I & 2.1 & $50-56$ & III & 48 \\
\hline \multicolumn{8}{|l|}{ RD-2 } \\
\hline $\begin{array}{l}\text { Foliated gneiss with bands of } \\
\text { banded gneiss }\end{array}$ & $0.0-7.0$ & Two & W-III & 0.17 & $27-32$ & IV & 24 \\
\hline $\begin{array}{l}\text { Banded gneiss and Foliated } \\
\text { gneisses }\end{array}$ & $7.0-15.0$ & Three & W-II to W-III & 1.46 & $34-56$ & III-IV & 40 \\
\hline $\begin{array}{l}\text { Foliated gneiss with bands of } \\
\text { banded gneiss }\end{array}$ & $15.0-25.5$ & Two plus random & W-II to W-III & 1.13 & $33-59$ & III-IV & 38 \\
\hline Foliated and banded gneisses & $25.5-26.5$ & Two plus random & W-I to W-III & 3.2 & $55-57$ & III & 51 \\
\hline $\begin{array}{l}\text { Foliated gneiss with bands of } \\
\text { banded gneiss }\end{array}$ & $26.5-30.0$ & Two & W-I to W-II & 0.17 & $28-36$ & IV & 26 \\
\hline \multicolumn{8}{|l|}{ RD-4 } \\
\hline Foliated gneiss & $0.0-20.0$ & Two plus random & W-III & 0.18 & $26-40$ & IV & 27 \\
\hline Foliated and banded gneisses & $20.0-26.0$ & Three & W-II to W-III & 0.33 & $33-41$ & III-IV & 32 \\
\hline Banded gneiss with schist bands & $26.0-30.0$ & Two plus random & W-I to W-II & 1.21 & $48-52$ & III & 44 \\
\hline \multicolumn{8}{|c|}{ 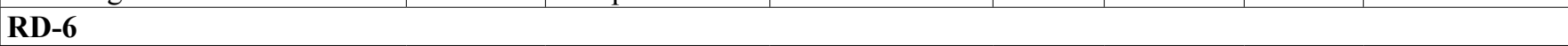 } \\
\hline $\begin{array}{l}\text { Foliated gneiss with bands of } \\
\text { banded gneiss }\end{array}$ & $0.0-19.0$ & Two & W-I to W-III & 1.60 & $30-58$ & III-IV & 42 \\
\hline $\begin{array}{l}\text { Foliated gneiss with bands of } \\
\text { banded gneiss }\end{array}$ & $19.0-22.5$ & One plus random & W-I to W-II & 4.6 & $58-61$ & II-III & 55 \\
\hline $\begin{array}{l}\text { Foliated gneiss with bands of } \\
\text { banded gneiss }\end{array}$ & $22.5-50.0$ & Three & W-I to W-II & 4.25 & $55-64$ & II-III & 55 \\
\hline \multicolumn{8}{|l|}{ RD-7 } \\
\hline Banded gneiss & $0.0-5.0$ & Two plus random & W-II & 0.93 & $44-50$ & III & 41 \\
\hline Banded gneiss & $5.0-13.0$ & Two plus random & W-I & 4.13 & $56-62$ & II-III & 54 \\
\hline $\begin{array}{l}\text { Banded gneiss with bands of } \\
\text { foliated gneiss }\end{array}$ & $13.0-37.5$ & Two plus random & W-I to W-II & 4.76 & $57-65$ & II-III & 56 \\
\hline
\end{tabular}


Table 7: Results of dilatometer test to different boreholes at dam site

\begin{tabular}{|c|c|c|c|c|c|c|c|}
\hline \multirow[b]{2}{*}{$\begin{array}{c}\text { Bore } \\
\text { Hole No }\end{array}$} & \multirow[b]{2}{*}{$\begin{array}{c}\text { Depth } \\
\text { (m) }\end{array}$} & \multicolumn{3}{|c|}{ Strata Description } & \multirow[b]{2}{*}{$\begin{array}{l}\text { Deformation } \\
\text { Modulus } \\
\text { (GPa) }\end{array}$} & \multirow[b]{2}{*}{$\begin{array}{c}\text { Shear } \\
\text { Modulus } \\
\text { (GPa) }\end{array}$} & \multirow[b]{2}{*}{ Remarks } \\
\hline & & Description & $\begin{array}{l}\text { Core } \\
\text { Recovery } \\
(\%)\end{array}$ & $\begin{array}{c}\text { RQD } \\
(\%)\end{array}$ & & & \\
\hline DH-12 & 40.00 & $\begin{array}{l}\text { Bandded } \\
\text { gneiss }\end{array}$ & 98.00 & 59.00 & 7.90 & 5.13 & $\begin{array}{l}\text { One joint set i.e. foliation joint, rock } \\
\text { is fresh and joint surface is rough } \\
\text { undulating }\end{array}$ \\
\hline DH-13 & 56.00 & $\begin{array}{l}\text { Bandded } \\
\text { gneiss }\end{array}$ & 62 & 10.00 & 5.72 & 3.72 & $\begin{array}{l}\text { One joint set i.e. foliation joint, rock } \\
\text { is fresh to slightly weathered and joint } \\
\text { surface is rough planar }\end{array}$ \\
\hline DH-19 & 42.00 & Foliated gneiss & 63.00 & 0.00 & 2.28 & 1.48 & $\begin{array}{l}\text { One joint set i.e. foliation joint, rock is } \\
\text { moderately weathered and joint surface } \\
\text { is smooth undulating }\end{array}$ \\
\hline DH-23 & 48.00 & $\begin{array}{l}\text { Bandded } \\
\text { gneiss }\end{array}$ & 60.00 & 0.00 & 2.89 & 1.88 & $\begin{array}{l}\text { One joint set i.e. foliation joint, rock is } \\
\text { moderately weathered and joint surface } \\
\text { is smooth planar }\end{array}$ \\
\hline
\end{tabular}

Table 8: Results of in-situ shear test

\begin{tabular}{|c|c|c|c|}
\hline \multirow{2}{*}{$\begin{array}{c}\text { Drift } \\
\text { No }\end{array}$} & \multirow[t]{2}{*}{ Type of Test } & \multicolumn{2}{|c|}{ Peak shear strength parameter } \\
\hline & & Cohesion $\left(\mathrm{kg} / \mathrm{cm}^{2}\right)$ & Apparent friction angle ( $\Phi)$ \\
\hline LD-3 & Concrete to rock interface & 0.7463 & 42.58 \\
\hline LD-5 & Concrete to rock interface & 0.81 & 42.03 \\
\hline LD-2 & Rock to rock interface & 0.419 & 44.22 \\
\hline RD-6 & Rock to rock interface & 0.2823 & 43.04 \\
\hline
\end{tabular}

considering the necessity in the overall context of the design requirements of the dam. The values for the bulk dry density of foliated gneisses are 2.79 to 2.83 , banded gneisses 2.66 to 2.77 , amphibolite gneiss 2.76 to 3.01 and for schistose quartzite 2.72 to $2.77 \mathrm{~g} / \mathrm{cc}$; the saturated bulk density values for foliated gneisses are 2.80 to 2.84 , banded gneisses 2.67 to 2.78 , amphibolite gneiss 2.77 to 3.02 and for schistose quartzite 2.73 to $2.78 \mathrm{~g} / \mathrm{cc}$ belongs to high density category. The porosity and water absorption values are quite low. The slake durability index is more than 96.50 , which indicate high durability. Uniaxial compressive strength and deformability characteristic i.e. Modulus of Elasticity and Poisson's ratio were determined. According to strength classification criterion for rock substance, proposed by ISRM (1981), the rocks are of low to moderate strength in saturated condition. Banded gneisses show higher strength than the foliated gneisses due to the orientation of foliation planes. The Modulus of Elasticity values are ranges from 2.65 to $38.95 \mathrm{GPa}$ and fall under fair to very good rock mass category. Some values of Poisson's ration are abnormally low, might have arised due to erratic lateral deformation of samples during the uniaxial compression testing. It is recommended to take a Poisson's ratio between 0.20-0.25 for design purpose. The tensile strength of schistose quartzite is more than the foliated, banded and amphibolite gneisses. Foliated and banded gneisses shows lower cohesion compared to calc silicate and amphibolite gneisses, the magnitude of drop depends on the mineralogy and rock formation. Friction angle is varying from $38^{\circ}$ to $49^{\circ}$ possible due to variation in roughness of the fractured surface. The ultrasonic pulse wave method was used to find out the velocity of compression (or primary or ' $\mathrm{P}$ ') and secondary (or shear or transverse or ' $\mathrm{S}$ ') wave, through rock specimens. The range of $\mathrm{Vp}$ for gneisses is 1.757 to $4.695 \mathrm{~km} / \mathrm{sec}$ and the corresponding ranges for Vs are 1.195 to $3.062 \mathrm{~km} / \mathrm{sec}$, showing the rocks have low to very low sonic velocity. Ultrasonic velocity measurements indicate that the rocks are highly fractured.

\section{GEOTECHNICAL APPRAISAL}

On the basis of above investigations/studies, geotechnical appraisal of the dam site i.e. left abutment, right abutment and central river section is discussed. On the left abutment the drill holes data reveals an overburden cover, consisting of slope wash and riverine material varying between $4.0 \mathrm{~m}$ at El $2019.50 \mathrm{~m}$ to $31.0 \mathrm{~m}$ thickness at El $1851.67 \mathrm{~m}$. Underneath the debris, riverine deposit consisting of sub-rounded pebbles of quartzites and genisses are noted. The sound rock is found to occur at $28-43 \mathrm{~m}$ (av. $35.6 \mathrm{~m}$ ) depth along the dam axis. Synthesis of surface and subsurface data on the left abutment indicates that the destressed limit at El $2010 \mathrm{~m}$ is of the order of $38 \mathrm{~m}$, at El $2000 \mathrm{~m}$ is $41 \mathrm{~m}$, at RL $1943 \mathrm{~m}$ is $48 \mathrm{~m}$, at El $1920 \mathrm{~m}$ is $57 \mathrm{~m}$ and at EL $1885 \mathrm{~m}$ is of the order of $64 \mathrm{~m}$. Tentatively the stripping limit on the left abutment may be of the order of $34 \mathrm{~m}$ to $50 \mathrm{~m}$. Left abutment would involve large scale excavation in bouldery overburden.

On the right abutment the drill holes data reveals overburden cover consisting of slope wash material varying between $0.5 \mathrm{~m}$ at El $1930.79 \mathrm{~m}$ to $1.5 \mathrm{~m}$ thickness (inclined length) at El $1850.75 \mathrm{~m}$. The sound rock is found to occur 


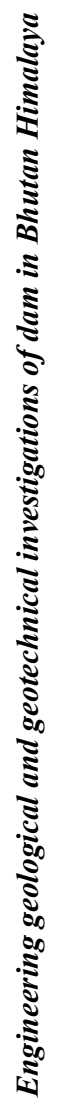

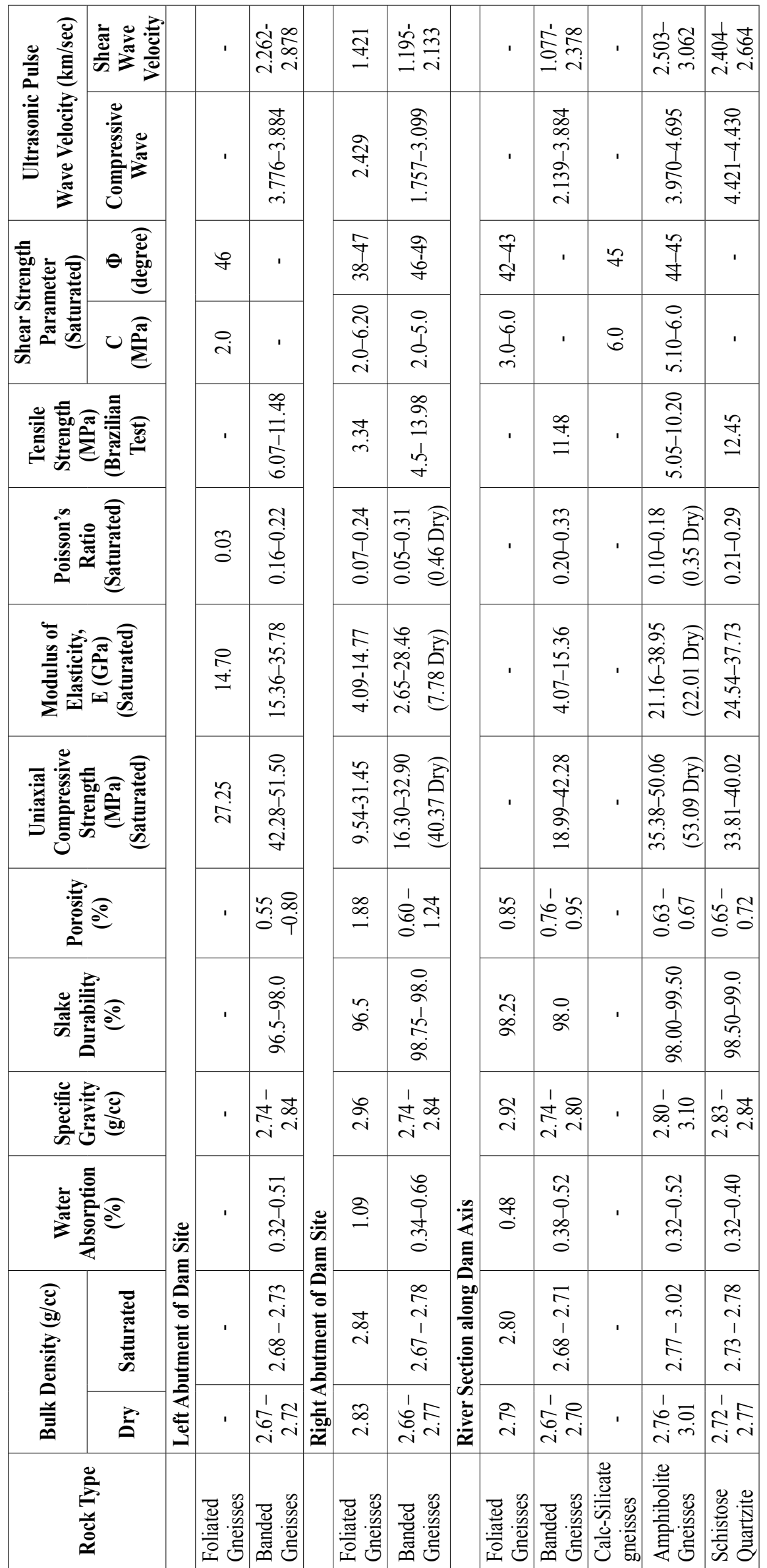


at $22-35 \mathrm{~m}$ (av. $28 \mathrm{~m}$ ) depth along the dam axis. Surface and subsurface data on the right abutment indicates that the destressed zone at El $2010 \mathrm{~m}$ is of the order of $40 \mathrm{~m}$, at El 1910 $\mathrm{m}$ is $33 \mathrm{~m}$, at El $1885 \mathrm{~m}$ is $30 \mathrm{~m}$, at El $1875 \mathrm{~m}$ is $28 \mathrm{~m}$ and at El $1865 \mathrm{~m}$ is of the order of $23 \mathrm{~m}$. A probable line defining destressed zone is indicated in the geological section, depth of stripping in the right abutment would be of the order of 18-30 $\mathrm{m}$. However, on large scale rock mass removal the slope would further be destressed inducing slope deformation and seepage through relieved and opened up discontinuities. This warrants providing grouting even beyond the distal end of the dam, this could be executed either through a grouting tunnel or resorting to fan-grouting from the surface.

Overburden on the dam abutments which may constitute about $25-30 \%$ of total excavation, should be tackled by ripping and dozing while remaining excavation will require drilling and blasting. The stripping limit is to be restricted within the destressing zone and cut off for permeability should be 5 to 10 lugeon. Destressing on either abutments necessitating deep stripping level around 18-37 m or even $50 \mathrm{~m}$ at some places. Stripping should be done parallel to or less than the dip amount of valley dipping joints to avoid the instability of abutments. Further destressing on abutment on large scale rock mass removal; destressed open joints may pave way to seepage through abutment specially in right abutment. At El 2008 m, stability of the slope above the excavated level of foundations those are cut slope in bedrocks on the right abutment and debris material on the left abutment may require slope stability measures. Foundation stripping on the left abutment may further destablise the slope and therefore in order to plan preventive measures, specific study may be taken up during pre-construction stage for stability check after generating the geometry of the slope. To avoid destabilisation of slopes control blasting may be adhered.

Two drill holes (DH-15 and DH-16) on the right bank of river channel, one on left bank (DH-02) and one (DH-08) on the centre of river channel were drilled. Drill holes data indicate that the close to right bank, bedrock is available at depth of $22 \mathrm{~m}$ (El $1828 \mathrm{~m}$ ) whereas on the left bank the thickness of the overburden is $31 \mathrm{~m}$ (El $1820.67 \mathrm{~m})$. In DH-8 located $70 \mathrm{~m} \mathrm{u} / \mathrm{s}$ of dam axis on the centre of the channel, the bed rock occurs at $27.43 \mathrm{~m}$ depth (El $1822 \mathrm{~m}$ ). Based on exploratory data erratic weathering is indicated. In general, moderately fresh rock is available at elevation ranging from Els $1822.5 \mathrm{~m}$ to $1813.2 \mathrm{~m}$. Anomalous change in foliation attitude and associated profuse permeation by quartz veins is also noted, this could be attributed either to steepening of beds in the proximity to axial shear zone or to locally profuse permeation and injection by quartz veins. Cores retrieved from the drill hole indicate steep dipping foliation $\left(50^{\circ}-60^{\circ}\right)$ right upto $59.0 \mathrm{~m}$ depth (i.e. El $1791.0 \mathrm{~m}$ ); at further depth the intercepted foliation in alternate bands of gneisses has low angle $\left(15^{\circ}-30^{\circ}\right)$ disposition. The drill hole seems to have gone along the over-steepened limb of the anticlinal fold which at depth intercepted part of sub-horizontally disposed foliation (S1) at the axial zone of the fold (F3). Based on the surface and subsurface data it is apparent that the steepened segment of the anticline lies close to the right bank of the Wang Chhu River. In view of the medium values of the permeability (max. 44.57 lugeon in DH-17, between test section El $1803.7 \mathrm{~m}$ to 1797.7 $\mathrm{m})$, the discontinuities may frequently be open and would easy path for seepage. Hence a plan for impermeabilising these and to render the foundation monolithic shall have to be formulated during initial planning. The sound rocks have been encountered in drill holes at the RL $1813 \mathrm{~m}$ (deepest depth) and require a stripping of the order of 29 to $36 \mathrm{~m}$. The rock mass properties of the left and right abutment and central river section at the foundation level, combining geological data, drilling data and geophysical data are given in Table 10 .

\section{DISCUSSIONS AND CONCLUSIONS}

Sedimentation rate of $1 \mathrm{~mm} /$ year/sq $\mathrm{km}$ has been adopted for the designing of the dam after the site specific sedimentation data and data from the various projects in neighboring basins. The Bunakha HE Project site lies in vicinity of seismic Zone $\mathrm{V}$ of the seismic zoning map of India (IS: 1893 \{Part $1\}: 2002)$. The probable intensity of earthquake in seismic zone $\mathrm{V}$ corresponds to Intensity IX on comprehensive intensity scale (MSK64). The recommendations for the site specific earthquake design parameters for the site are based on the studies carried out related to the tectonics, regional geology, local geology around the site, earthquake occurrences in the region around the site and the seismotectonic setup of the area. The project area is lies in MCT Zone. The site specific design earthquake parameter for Maximum Considered Earthquake (MCE) condition is estimated to $\mathrm{Ms}=8.0$ magnitude earthquake occurring at MCT. The dam is analysed for the "maximum considered earthquake". The Peak Ground Acceleration (PGA) value for MCE conditions is estimated to $0.36 \mathrm{~g}$ and for Design Basis Earthquake (DBE) conditions is estimated to $0.18 \mathrm{~g}$ (IIT Rorrkee, 2011).

The grade of the rock mass as evaluated from the drill holes cores, core recoveries, RQD and drifts data has RMR values varying from 26 to 65 and fall under the good to poor rock mass category. Calc-silicate gneisses thickness varies from $0.5 \mathrm{~m}$ to $6.5 \mathrm{~m}$ have been logged at different depth from boreholes DH-15, DH-16 and DH-17 below foundation level, so this parameter should be taken into consideration in the design. At the dam site, the downstream (low) dipping rocks associated with low angle $(<19)$ southerly (downstream) plunging antiformal structure may pose a problem of stability of the dam, coupled with potential problem of leakage from the reservoir along the low dipping foliation planes/joints/shears and thus need to be treated by adopting suitable stabilization measures. Curtain grouting is recommended to control any downstream flow/leakage from reservoir through the low dipping foliation parallel shear zones in bed rocks. Two to three rows of curtain grouting is recommended at $6.00 \mathrm{~m} \mathrm{c} / \mathrm{c}$ to be done in the first instance and later, the spacing is to be reduced at $3.00 \mathrm{~m} \mathrm{c} / \mathrm{c}$ or $1.5 \mathrm{~m} \mathrm{c} / \mathrm{c}$ based on the permeability tests done through check holes. The depth of the grouting hole 
Table 10: Properties of rock mass at the foundation level of left $\&$ right abutment and river section of the dam site

\begin{tabular}{|c|c|c|c|c|c|c|c|c|c|}
\hline Segment & Rock type & Joints & $\begin{array}{l}\text { Weathering } \\
\text { grade }\end{array}$ & $\begin{array}{c}\text { Core } \\
\text { Recovery } \\
\%\end{array}$ & $\begin{array}{c}\text { RQD } \\
\%\end{array}$ & $\begin{array}{c}\mathbf{V p} \\
(\mathbf{k m} / \mathbf{s e c})\end{array}$ & $\begin{array}{c}\text { Water } \\
\text { table (m) }\end{array}$ & $\begin{array}{c}\text { Permeability } \\
\text { (lugeon) }\end{array}$ & $\begin{array}{c}\text { Depth of } \\
\text { acceptable } \\
\text { foundation } \\
(\mathbf{m})^{*}\end{array}$ \\
\hline $\begin{array}{l}\text { Left } \\
\text { Abutment }\end{array}$ & $\begin{array}{l}\text { Banded } \\
\& \text { foliated } \\
\text { gneisses }\end{array}$ & $\begin{array}{l}\text { Inclined } \\
\text { and } \\
\text { vertical }\end{array}$ & W-I to W-II & $6.0-74.0$ & $\begin{array}{l}0.0- \\
66.7\end{array}$ & 3.0 to 3.5 & $\begin{array}{l}1.0 \text { only } \\
\text { in DH-17 }\end{array}$ & $\begin{array}{l}24.06 \text { to } \\
44.72\end{array}$ & $\begin{array}{l}30.0 \mathrm{~m} \text { at } \mathrm{El} \\
2010,34.0 \mathrm{~m} \text { at } \\
\mathrm{El} 2000,29.0 \mathrm{~m} \\
\text { at El } 1943,33 \mathrm{~m} \\
\text { at El } 1920 \& \\
30 \mathrm{~m} \text { at El } 1885\end{array}$ \\
\hline $\begin{array}{l}\text { Right } \\
\text { Abutment }\end{array}$ & $\begin{array}{l}\text { Banded } \\
\& \text { foliated } \\
\text { gneisses }\end{array}$ & $\begin{array}{l}\text { Inclined } \\
\text { and } \\
\text { vertical }\end{array}$ & W-I to W-II & $50.0-93.0$ & $\begin{array}{l}11- \\
77.3\end{array}$ & - & $\begin{array}{l}3.0 \\
\text { (inclined } \\
\text { depth) } \\
\text { only in } \\
\text { DH-14 }\end{array}$ & 1.31 to 8.99 & $\begin{array}{l}30.0 \mathrm{~m} \text { at } \mathrm{El} \\
2010,33.0 \mathrm{~m} \text { at } \\
\mathrm{El} 1910,23 \mathrm{~m} \\
\text { at } \mathrm{El} 1885 \mathrm{~m}, \\
25 \mathrm{~m} \text { at } \mathrm{El} 1875 \\
\& 22.0 \mathrm{~m} \text { at } \mathrm{El} \\
1865 \mathrm{~m}\end{array}$ \\
\hline $\begin{array}{l}\text { River } \\
\text { Section }\end{array}$ & $\begin{array}{l}\text { Foliated, } \\
\text { banded \& } \\
\text { amphibolite } \\
\text { gneisses }\end{array}$ & $\begin{array}{l}\text { Inclined } \\
\text { and } \\
\text { vertical }\end{array}$ & W-I to W-III & $5.0-76.0$ & $\begin{array}{l}0.0- \\
40.0\end{array}$ & 3.5 to 4.5 & $\begin{array}{l}0.5-6.0 \\
\text { (inclined } \\
\text { depth) }\end{array}$ & $\begin{array}{l}16.62 \text { to } \\
41.56\end{array}$ & $\begin{array}{l}36 \mathrm{~m} \text { on left } \\
\text { bank and } 29 \mathrm{~m} \\
\text { on right bank } \\
\& \text { centre of the } \\
\text { river }\end{array}$ \\
\hline
\end{tabular}

at any particular foundation elevation shall be $0.75 \mathrm{H}$ where ' $\mathrm{H}$ ' is the depth of water from the foundation elevation to Full Reservoir Level (FRL). Curtain grouting shall be done before the reservoir is impounded. Consolidation grouting is recommended throughout the base of the dam, after the completion of excavation and prior to placement of concrete.

The deepest foundation level at river bed (El $1813.0 \mathrm{~m}$ ), as suggested based on exploratory drill holes results and seismic tomography survey, might change during excavation depending on the depth of competent foundation rock to be encountered during excavations and the construction methodology. At the time of foundation excavation, a floor level geological plan depicting all discontinuities including shear planes should be prepared and accordingly treatment plan should be modified. It is inferred from the present study that the strike length of some shear zone may be more, spreading across the reservoir area in the upstream and river section on the downstream of the dam, those may guide leakage through the foundation. The foundation stresses for such a type of high dam, can be safely transmitted to the rocks of the types encountered which are not very steeply dipping. But rich presence of micaceous/shear zone layers can pose shear strength problems. The shear strength parameters of rock to rock and concrete to rock interface were conducted inside the drifts and these parameters should be taken into consideration in the design of dam.

The shape of gravity RCC dam, its thickness at the contact with the foundation, and the slope of the concrete rock contact are important factors providing stability for the structure. The base width of the gravity RCC dam is kept 196 $\mathrm{m}$ to ensure sufficient factor of safety against sliding at contacts and deeper joints in foundation rocks. Transversely, the foundation contact has been kept horizontal and longitudinally, the profile is smooth without abrupt changes to minimize stress concentration. Provision of shear keys at the heel of the dam will improve the stability.

All these data were used by the designer for the economic and fail-safe design of the dam. For the computation of the factor of safety of dam at the concrete-to-rock contact, engineering geological and geotechnical data generated during these investigations were used.

\section{ACKNOWLEDGEMENTS}

This work forms a part of project sponsored by THDC India Ltd, so we sincerely thank the Management THDC India Ltd for the same. We also sincerely acknowledge the support extended by Mr. Rajeev Bishnoi, GM (Design), Mr. Sanjay Singhal, Sr. Manager (Design), Mr. J.S. Rawat, Sr. Manager (Civil) and Mr. Sanjeev Kumar Mittal, Manager M/s THDC India Ltd for the field investigations at the BHEP site and providing the in-situ and laboratory data, which helped us to incorporate the same in the manuscript. We thank Dr. G.M. Nagaraja Rao, Scientist NIRM for his valuable suggestions during the interpretation of laboratory test results. We thankful to Dr. V. Venkateswarlu, Director, NIRM for encouragement and permission to send the manuscript for publication. 


\section{REFERENCES}

Barton, N., Lien, R. and Lunde, J., 1974, Engineering classification of rock masses for the design of tunnel support. Rock Mechanics, v. 6(4), pp. 189-236.

Bhargava, O. N. (Ed.), 1995, Bhutan Himalaya A Geological Account. GSI Special Publication. No. 39, 245 p.

Bieniawski, Z. T., 1989, Engineering rock mass classification. John Willey \& Sons, New York, 251p.

Chowdhury, A. K., 1993, Report of the reconnaissance geotechnical evaluation of Bunakha hydroelectric project, District Chukha, Bhutan. Unpub. Geol. Surv. India, Progress Report of F.S. 1992-93.

Chowdhury, A. K., 1995, Final report on the feasibility stage geotechnical investigation of Bunakha hydroelectric project, Chukha District, Bhutan. Geol. Surv. India, Progress Report of F.S. 1994-95.

Gansser, A., 1983, Geology of Bhutan Himalaya. Birkhauser Verlag, Basel. 181p.

Geological Survey of India, 1979-80, Geological and mineral map of Bhutan on 1:5,00,000 scale.

I. I. T. Roorkee, 2011, Report on site-specific earthquake parameters studies for Bunakha hydro electric project, Bhutan. Unpubld. Department of Earthquake Engineering IIT Roorkee report.

IS 1893 (Part 1), 2002, Criteria for earthquake resistant design of structures, Part 1 - general provisions and buildings. Bureau of Indian Standards, New Delhi, 36p.

ISRM, 1978, Suggested methods for the quantitative description of discontinuities in rock masses, (Coordinator, Barton, N.) Int. j. Rock mech. Sci. and Geomech. Abstr., v. 15, pp. 319-368, Pergamon.

ISRM, 1981, Suggested methods for rock characterization, testing and monitoring. Commission on Testing Methods, International Society of Rock Mechanics, Brown, E.T. (Ed.), Pergamon Press, 211p.

Jangpangi, B. S., 1978, Stratigraphy and tectonics of Bhutan Himalaya. In Saklani P.S. ed., Tectonic Geology of Himalaya. Today's and tomorrow Publ., New Delhi, pp. 221-242.

Jha, P. C., Balasubramanaim, V. R., Sandeep, N., Sivaram, Y. V. and Butchi Babu, B., 2011, Seismic refraction and tomography survey at Bunakha hydro electric project, Bhutan. Unpubld. NIRM Report No. GP-10-03.

Koike, T., 2001, On the outcrop of the main central thrust at Tsirang-Daga road section, Bhutan Geol. No. 5, pp. 1-3.

Koike, T., 2002, Structural problem of the Paro formation southwestern Bhutan. Bhutan Geol., News Letter Sl. No. 6, pp. 10-18.

Mishra, P. S. and Sanwal, R., 1994, Report of feasibility stage geotechnical investigation of Bunakha hydroelectric project, Chukha District, Bhutan. Unpub. Geol. Surv. India, Progress Report of F.S. 1993-94.

Nawani, P. C., Naithani, A. K., Singh, L. G., Rawat, D. S., Manoj Kumar and Jain, P., 2011, A detailed report on engineering geological investigations of Bunakha hydro electric project (180 MW), Chukha Dzong, Bhutan. Unpubld. NIRM Report No. EG-10-02, 196p. 